Max-Planck-Institut für demografische Forschung

Max Planck Institute for Demographic Research

Konrad-Zuse-Strasse 1 - D-18057 Rostock · GERMANY

Tel +49 (0) 3812081 - 0; Fax +49 (0) 3812081 - 202;

http://www.demogr.mpg.de

MPIDR WORKING PAPER WP 2006-053

DECEMBER 2006

\title{
The demography of family reunification: from circulation to substitution in Gambian Spain
}

Caroline H. Bledsoe (bledsoe@ demogr.mpg.de)

This working paper has been approved for release by: Gerda Ruth Neyer (neyer@ demogr.mpg.de) Deputy Head of the Laboratory of Contemporary European Fertility and Family Dynamics.

(C) Copyright is held by the authors.

Working papers of the Max Planck Institute for Demographic Research receive only limited review. Views or opinions expressed in working papers are attributable to the authors and do not necessarily reflect those of the Institute. 


\title{
The Demography of Family Reunification: From Circulation to Substitution in Gambian Spain
}

\author{
November 2006 \\ Caroline H. Bledsoe \\ Department of Anthropology \\ Northwestern University \\ Evanston, Illinois 60208 USA
}

Acknowledgements: The Max Planck Institute for Demographic Research in Rostock, Germany has supplied the funding that made this paper possible. I am indebted well to many individuals for their contributions to the thinking, and whose insights as well as generosities of time and engaged critique have been pivotal.

Among them have been Gunnar Andersson, Yussuf Badji, Pau Baizan, Laura Bernardi, Adama Bojang, Jalika Bojang, Anna Cabré, Eva Cham, Bully Diawara, Albert Ficat, Vicent Fouda, Jan Hoem, Jalika Jam, Anna

Jeremies, Adriana Kaplan Marcusán, Boury Marianne Rosalie Mendy, Ferran Moreno, Vicens Galea Montero, Gerda Neyer, Merixtell Pérez, Dan Rodríguez García, Augustin Senghor, Mohamad Saybo Silla, Alassane Silla, Montse Solsona, Andres Vikat, Josep Vilarmau, and Ana M. Zaragoza Bas.

This paper was presented for the Bay Area Colloquium in Population, Berkeley, California, September 7 , 2006. It builds directly on work with Papa Sow, René Houle, and Nuria Empez, to whom I am especially grateful. 


\section{Introduction}

As a topic in the age of transnationalism, reproductive life has drawn surprisingly little explicit attention in the social sciences.1 The question of reproduction in the migration context has, however, been of interest to demographers, who have asked if immigrants' youthful age pyramids might help solve the crisis of a rapidly aging Europe (United Nations, 2000). Most quickly concluded, as did Leridon, 2 that on the whole, this will not happen. Not only are fertility levels in developing countries themselves falling rapidly, but most immigrants irrespective of origin quickly adopt the fertility levels of their host countries (see Kulu's review, 2005).

For immigrants themselves, two concerns about reproductive life loom large. First is the physical risk that reproduction entails. Birth is an event of potentially mortal consequences for both mother and child in some areas of the world. Women who bear children in states where they are not recognized as legal residents may drop below the horizon of national health care. Second, while conducting a reproductive life under any conditions is a monumental task, a transnational existence means that the laws of a state to which one does not belong may set the terms by which one's reproductive sequence must transpire. What is more, these rules may change specifically to disrupt pathways in which marginal immigrants have tried to stitch a life together. When the smallest shifts in national rules of belonging can shatter personal security, trying to sustain any degree of predictability for conducting an intensively invested reproductive sequence under such conditions seems an impossibility. 3

I believe that reproduction and marriage are rapidly becoming the major political battleground of immigration struggles, and they appear to be doing so through the logics generated by family reunification policies. The UN's family reunification initiative, drafted to become one of the great humanitarian measures of the twentieth century, was hardly intended to be a weapon of exclusion. But with businesses outsourcing their labor needs and asylum possibilities all but disappearing, the rush by advantaged nations to erect physical boundaries is rendering family reunification the default pathway to legitimate transnational mobility. Nor do the potentials for exclusion stop there. Fences are being erected within family relations, and on the basis of family reunification criteria themselves. Demands for DNA evidence of relationships are rising, and there is increased policing of marriage to rule out unions contracted for immigration "convenience." At the same time, qualifications for family reunification are shrinking to a core of highly circumscribed ties centering on legally married heterosexual couples and biological parent/child relationships. These allowable ties include increasingly fewer categories with tighter age windows and fewer allowable variations in sexual preference and marital status. Rather than standing as a right, family reunification principles have created hurdles, and precisely at the lines that mark relationships that societies most tend to hold as core.

Like any other cultural referent, the notion of family reunification can not only be contentious: it is also unstable. It assumes a "partible self": an identity comprised of facets of the self or of temporal segments of its life course. Family reunification doctrine converts these facets of self to values that are transactable with reference to two things: another person or persons, and another country. Facets of self, that is, to have any value, must be converted with reference elsewhere and to other people. Precarious and idiosyncratic, family reunification principles rest on potentials rather than inherent characteristics and on relationships that are inevitably fluid.

1 This has begun to change in anthropology and sociology. For just a few examples: Ginsburg and Rapp (1995), Hondagneu-Sotelo (1995, 2002), Hochschild (2000), Inda (2002), Whiteford and Manderson (2003), Cole and Durham et al. (in press); and the papers in a forthcoming volume edited by Carolyn Sargent and Carole Browner. 2 Vieillissement démographique et migrations : quand les Nations Unies veulent remplir le tonneau des Danaides / Henri Leridon (juin 2000).

3 Jastram (2003) notes, with some optimism, that in the light of the increasing volume of global movement, "Immigration policymakers will increasingly be called upon to recognize the rights and realities of families living across borders." 
The demands of family reunification policy are in some respects no different from immigration allowances based on job skills, political persecution, or even winning a "lottery visa." All oblige people to emphasize or create a quality of the self that might enhance their value with reference to a location to which they do not belong, and to downplay other facets of self that might undermine their case. Context is everything. In Israel, religion holds convertible migration value; in countries like the Netherlands, same-sex orientation is not only an acceptable attribute for immigrants but a potential qualifier for asylum. In the case of family reunion, however, it is some explicitly relational quality that is put up for exchange: a quality centered, moreover, on what society holds as the closest and most moral of social ties.

With the lines of tension established from the outset, the dynamics of family reunification policy set up the potential for very different migration dynamics according to the relational attributes individuals may claim, or to what they believe may hold the most viable conversion values. With family reunification emerging as the narrowing window of transnational mobility for people from poor regions of the world, it should hardly be surprising that the possession of those personal characteristics that may have the greatest conversion value across a national boundary also places a migration premium on those individuals who can be construed as fitting a particular family profile. (See APPENDIX for some vivid cases.) Growing pressures, positive or negative, in fact may intensify efforts to select individuals with the best chances of presenting a persuasive case for having those relational characteristics that family reunification policy allows to cash in on those characteristics. In doing so, they may intensify efforts, or delegate others, to move across the national boundaries, and into the specified role configurations, that will most likely allow such conversions to occur. Individuals may thus try to take advantage of potential transactable values that their socially defined demographic relationships might carry with reference to a particular migration endpoint. The structure itself, in sum, creates incentives to offer up for speculation pieces of a partible self that might take on such value, whether individuals are moved to try to seize on -- or fashion -- attributes in themselves, or others do it for them.

One suspects as well that in practice the dynamics of migration must work very differently in practice for individuals, depending on the positions they might claim in any particular pre-defined nuclear group, and according to the immigration dynamics in a particular place, at a particular historical moment. By far, however, the most sweeping categories around such potential lines of conversion and, hence, strategy are built are conjugal and parent-child ties. With Western society's strong emphasis on the primal quality of the mother-child relationship, I focus on the relationship of women to children among immigrants at three levels of magnification. The first is Spain, the country that has now taken the lead as the major immigrant-receiving country in Europe. I focus secondly on Africans, the group that has provided most of its unskilled labor in recent years but which also, arguably, experiences the most difficulties making a stable immigrant life work there. After examining some broad patterns, I turn to marriage and the reproductive life that revolves around it specifically for the immigrant group that appears to have tried hardest to make such a life possible:

Gambians.4 Throughout, I refer for the most part to individuals in Spain by the nationality that they have provided to the official sources. Immigrants who were born elsewhere and who have now become naturalized are important as well. Those specific cases cannot be detected, however, because people of Spanish nationality are absorbed into the records simply as "Spanish." Hence, I use nationality here because it may be a more direct statement of present identity. The further caution, however, is that though in some cases, national identity assignation is not the one that the sources inscribe, for example, for people who try to claim a nationality that may give them better chances for asylum. In any case, most African-born individuals in Spain who declare themselves to the official sources do not have Spanish nationality, whether because of their short duration in the country, or because of exclusion.

My interest in Gambians in Spain began with the discovery by my colleague (demographer) René Houle that their total fertility rate for 1996-2000 was 3.67 children per woman (Bledsoe, Houle, and Sow, ms.). For Africa, this is nothing remarkable. In the Spanish context, however, it means that Gambians living in a country with one of the lowest fertility rates in the world appear to have one of the highest fertility rates in

4 In this paper I refer to "Gambians in Spain," though I distinguish, when appropriate, between individuals with Gambian nationality and Gambian-born individuals. 
Europe. Building on this observation, the present paper presses on to consider on the implications of family reunification policies that insist on one spouse per person for an immigrant group that maintains close and ongoing ties to a polygamous homeland. I will argue that Gambians in Spain - men, women, and children -are caught between two sets of principles. On the one hand are those laid out in the UN document called the "Convention on the Rights of the Child," 5 which advocates the rights of children to the care and company of both parents, whether defined biologically or by legitimate social convention. On the other are the principles of family reunification, $\mathbf{6}$ which limit the marital couple in a "family" to one spouse. Pitting the "rights of the child" against those of women for family systems that have long incorporated polygynous dynamics, the "integrity" (CRC language) of the very connection itself that family reunification policy claims to safeguard that between child and both parents -- is undermined for many Africans in a European context. Despite the instruments' origins in the spirit of benevolence, the ensuing logical structure it generates may well create the conditions for unity. It also, however, creates the grounds for separation between women and their children, a separation which, along with marital separation, may be most visible later in a woman's reproductive life.

For women of any nationality whose value as family members stems from their marital and reproductive potential across a national boundary, approaching the end of reproductive life may arouse considerable anxiety. In the case of Gambians in Spain, coming from a polygynous homeland, the tensions that Spanish family reunification policy creates in its limit of one spouse at a time, together with the formidable financial legal and financial obstacles to bringing a family member, appears to produce a "slot" approach to immigrant positions within households. That is, it is far easier for immigrants from places like Africa to hold on to the position that each person's presence has created in the household than to relinquish it if he/she returns to Africa. Especially for the specific slot called "wife," this not only pits women against one another, but it sets women and their children onto independent locational pathways. It also makes the analyst's task challenging, because denominators are suddenly in question.

Based on observations drawn from the empirical demographic and ethnographic record as well as from logic, I speculate that the number of Gambian children present in Gambian households in Spain may be high not just because of the high fertility a largely-rural group from Africa may sustain, whether temporary or longterm, in a new place. Nor is it high solely because of what I call a significant "re-entry deterrence" hypothesis (see Bledsoe, Houle, Sow, ms.) Rather, the dynamics of polygyny in a monogamous context render women vulnerable to being cycled out of the marriage networks in Spain and replaced by younger wives. If this assessment has validity, it suggests that the one-at-a-time "slot" structure that family reunification policy imposes on spouses transforms patterns of circulation in marriage in Africa into strategies of "substitution" in Europe: sometimes desired by the various parties, sometimes not. Combined with the rule of no limits, in principle, on how many children a person can claim, for family reunification's sake, to have borne, this same substitution dynamic may create the grounds for an entirely different dynamic for children: one of "accumulation." Set in the context of a place that constitutes what nearly all would see as a more desirable place to raise children, what dilemmas does this create?

There is no inherent reason, of course, why children should be cared for by their "real" biological parents, and Sub-Saharan Africa, with perhaps the most complex and extensive fostering practices in the world, is itself the best counter-example (Goody, 1973; Bledsoe, 1990). It is also true that facets of the self are constantly assigned value and exploited across all sorts of social boundaries. Of interest here is simply the claim that family reunification doctrine makes for itself.

To address it, this paper experiments with just one of the many lines of what one might call the "demography of family reunification." By this I refer to the population dynamics surrounding the political and humanitarian policies drafted to ensure the rights of previously separated, or later acquired ties to, individuals who society defines as constituting a family. Is it possible to use demographic numbers to gain insight into what any contemporary social scientist would agree can be paradoxical and capricious effects of law and politics? If so, then such an endeavor might hold the potential to bring to light our own constructions of social categories

5 http://www.unhchr.ch/html/menu3/b/k2crc.htm

6 http://www.ohchr.org/english/issues/migration/taskforce/docs/familyreunification.pdf 
and groups, with a force of logic rivaled only perhaps by anthropology's cultural studies of new reproductive technologies, if not the parameters of motherhood itself.7 After looking at the possible effects of family reunification among other African nationals in Spain, I turn to immigrants from The Gambia. Despite their modest numerical representation among Spain's extensive migrant populations, the patterns that Spain-based Gambians manifest may be most important to understand the broader effects of family reunification on African immigrants as a whole.

\section{Data}

This paper draws on an assortment of sources, including some exploratory ethnographic fieldwork from 2005 in the northern province of Catalonia (Bledsoe, Houle, and Sow, ms.). 8 For numerical data, I rely on two official sources: the 2001 Census (Censos de Población y Viviendas 2001), the latest one available, and the years from 2001 to 2005 of the annual Spanish Municipal Register (the Padrón). Both sources are made generously accessible to the public by the Spanish government at www.ine.es.

The census and the register are at once a problem to an anthropologist and a windfall. They are hardly ideal, at least in their non-individualized public versions, for examining the dynamics of circulation among spouses or the accumulation of children. While any data are suspect, this is likely true especially for sources that purport to reflect the lives of people from places where marital relationships are fluid and keeping track of age holds so little interest. It may be even more true of such people occupying marginal migration niches in Spain, where there are so many undocumented immigrant workers, and where the production of accurate demographic information may be more a liability than a benefit. Equally problematic for analysis (though for very good safety reasons) is that the public sources do not allow the tracing of who goes where or when; nor were these sources collected with questions of circulation, accumulation, or substitution in view. Neither source allows a definitive identification of parents with the children they claim as their own, though the census does include a household component that shows numbers of children in broad age ranges that may or may not belong to the adults in the household. And while the census includes individuals' reported marital status, it is unclear who might be married to whom, whether in the household itself or in which national group.

Finally, the sources are very different from one another, making comparability hazardous. The census, conducted once every decade, contains a rich array of questions, including country of nationality and birth, marital status, household relationships, and so on; but 2001 was the last published version, and much has happened since then on the migration front in Spain and in Europe. The municipal register, on the other hand, consists simply of an annual compilation of the records from each Spanish municipality on those individuals who have come forward to declare themselves as residents, both out of legal obligation and to gain access to local educational, health, and social services. Neither necessarily requires legal residency, though this is always a worry of undocumented immigrants. However, people who are confronted at their door by a census taker may be unlikely to report residents with no legal rights to stay, meaning that the census likely underestimates immigrants. The register, by contrast, tends to overestimate them. This is likely so particularly at moments when word of a possible "regularization" or "amnesty" opportunity spreads. Spain held one such amnesty in 2005, and many undocumented immigrants living elsewhere in the EU who lacked legitimacy to travel under the protection of the European Union's Schengen Accord responded predictably. They flocked to Spain to register in hopes of gaining legal residency in a country from which they could then gain the legal ability to travel in Europe, and perhaps to return to later for work. Such facts can drive to distraction those whose professional lives require population counts that are as accurate as possible. However, the residue of the 2005 amnesty that is reflected in the latest Spanish register creates one of a number of points of triangulation which, when placed alongside the ethnography of Africa itself, can be used

7 See, for example, Franklin and Ragoné, 1998; Edwards et al., 1999; Rapp, 1999; Kahn, 2000; McKinnon and Silverman, 2005; Thompson, 2005; Johnson-Hanks, 2006.

8 This fieldwork was conducted in Catalonia with René Houle as well as with geographer Papa Sow and anthropologist Nuria Empez, over several short periods in 2004-2005. 
to explore the dynamics of marriage, reproduction, and migration among Spain's African immigrants. The picture they create, despite their limitations, is hardly a uniform one, even of its immigrants from individual continental zones. Rather, it is one of enormous variation. These variations, however, at least in the case of Africa, show some clear convergences.

Cultural anthropologists have taken a cautious approach to reliance on sources like census and vital registries, and to arguments made on the basis on numbers, and with good reason. Especially such reservations might be justified in the case of immigrants in marginal circumstances, who may want to speak only in the most indirect ways about their lives, and especially in any official record. But numbers, like any other form of cultural material, are about interpretation (see Hart's insightful reflections, forthcoming, on money and numbers). Like any other cultural materials, the numbers encoded by surveys and censuses contain voice, in so far as they trace culturally framed responses to culturally framed queries (see Bledsoe, 2002). If this is so, then the official Spanish demographic sources themselves can almost be seen as characters themselves, albeit very different ones, with ethnographic voice for the overall question of interest -- How do family reunification dynamics actually affect mother-child relations?

Exploring some simple numbers and graphic representations along with some exploratory ethnography, I search for ways to find the array of voices that these unlikely instruments might yield. For the most part, I follow demographic convention in examining what an anthropologist would consider "big" numbers. In certain instances, however, convention will have to be broken. To raise the level of magnification on patterns that seem to emerge, I try to break down the numbers into levels that would make most demographers uneasy. This device I flag by labeling charts " $a$ " and "b," rather than giving them separate numbers. On the other extreme, I do some "big picture" scans, decreasing the magnification level, to contextualize the position that immigrants like Gambians have come to hold in Spain. None of these disparate pieces provides conclusive evidence for the point that begins to emerge, but all, in time-honored anthropological tradition -are good to think with.

\section{The legal architecture of family reunification}

With unprecedented increases in transnational movement, the latter half of the twentieth century has witnessed the rise of an immense body of international law on the subject of family reunification. Family reunification policies are formal codes, drawing for the most part on UN conventions, 9 that would allow members of the family of a legal migrant - whether they became before or after the migrants' move -- to join his or her new country of residence. The most basic tenet underlying family reunification policy is the humanitarian right to a shared family life, irrespective of national boundaries (Jastram, 2003).10 Family reunification ideals, taking the family as the core unit of society, are given precedence even over the nation state, which thus has the responsibility to try to maintain the family's integrity, irrespective of its members' citizenship. In Europe, family reunification policies have evolved from numbers of documents generated by the UN and the whole of the EU, as well as by individual EU member states. Among the most important have been the 1990 ILO's statement on the Rights of Migrant Workers11 and the UN Convention on the Rights of the Child, approved in 1989 and now adopted by nearly all nations. The original instruments laid out broad principles, but they have generally allowed their signatory states to interpret and apply family reunification policies according to their own laws and situations.

9 http://www.un.org/documents/ga/res/45/a45r158.htm

10 The EU "Proposal for a Council Directive on the Right to Family Reunification," for example, spells out two additional principles, declaring family reunification necessary to the successful integration of third-country nationals residing lawfully in EU member states and a way to stabilize and deepen the roots of immigrants, enabling them to lead a "normal family life." COM/99/0638 final - CNS 99/0258, at http://eur-

lex.europa.eu/smartapi/cgi/sga_doc?smartapi!celexapi!prod!CELEXnumdoc\&lg=EN\&numdoc $=51999 \mathrm{PC} 0638 \& \mathrm{model}$ Eguichett

11 http://www.ilo.org/ilolex/cgi-lex/convde.pl?C097; see also, for discussion, http://www.ilo.org/public/english/standards/relm/ilc/ilc87/r3-1b.htm 
If any one element in international humanitarian doctrine trumps the individual's right to family life, it is the rights of "the best interests of the child," as spelled out in the various articles of the 1989 UN Convention on the Rights of the Child (http://www.unicef.org/crc/). According to Article 7.1, for example, "The child shall be registered immediately after birth and shall have the right from birth to a name, the right to acquire a nationality and, as far as possible, the right to know and be cared for by his or her parents." Article 7.2 charges its signatory states explicitly with the responsibility of ensuring the rights of protection even to children without a home nation. Turning to family reunification, Article 9.1 decrees that the child should be with his or her two parents, and preferably both of them, unless a separation is in the best interests of the child - for example, if the parents are deemed incapable or inappropriate caretakers. Finally, in Article 10.1, the CRC obliges (and the wording is careful here) states to deal with applications for reunification of parents and children - and either should have the right to leave as well as enter a state -- in a "positive, humane and expeditious manner."

Despite its simple language and its well-intended goals, nothing about family reunification is clear, either in rule or in policy practice. Not surprisingly, there has been considerable departure from what core family reunification doctrine appears to demand. It is important to point out first that although international organizations have tried to shore up the mandatory quality of the principles for their signatory states, they have little actual punitive power in cases of states that infringe these agreements.12 Although the most conservative way to refer to these agreements and the standards they attempt to uphold is in the sense of "best practices,"13 most countries, including Spain, have incorporated these rules into their own national policies.

Another source of deviation has arisen from the tendency of states to apply the principles selectively, sometimes within the scope allowed them by signing these documents and sometimes capriciously. In most cases, states appear to have tried to deflect the responsibilities the principles would seem to stipulate by attaching conditions to them. Most countries minimally demand, for example, that migrants demonstrate stable employment and adequate accommodation to support those family members they seek to bring, with these criteria usually being raised rather than lowered. For immigrants from poor countries, bringing anyone at all to a distant place can be a daunting financial and legal proposition. The sheer costs alone are enormous, with expenses required not just for transportation, but for middlemen, translators, lawyers, and the like. People who try to bring others whom the host country officials deem illicit themselves run the risk of deportation.

Even more problematic, possibly, from migrants' perspectives are states' powers to define what, precisely, a family consists of, who "belongs" closely enough to it to qualify for the right of reunification, and who can travel in which direction to enact this right.14 For African immigrants in Europe, EU family reunification laws extend to only a narrow range of people who they might call "family." Specifically excluded is a second wife, meaning that only one wife at a time can have a social security card, a health card, a residence permit, and so on. Excluded as well are any children not under the legal parental care of the immigrant or his/her spouse, including those with whom a man or one of his wives has been entrusted in fostering arrangements.

12 For a discussion of the obligation question regarding the treatment of refugees, for example, see http://www.unhcr.org/cgi-bin/texis/vtx/basics/opendoc.htm?tbl=BASICS\&id=3b0280294

13 http://rsdwatch.org/index_files/Page4725.htm

14 There is considerable immense variation even within the EU itself on allowable categories. Hinting at some of the definitional complexities surrounding conjugal life, the 1990 UN General Assembly's international convention on the protection of the rights of migrant workers and members of their families describes the obligations of states to facilitate the reunification of migrant workers with "their spouses or persons who have with the migrant worker a relationship that, according to applicable law, produces effects equivalent to marriage..." (ref). For an extensive analysis, see the Family Reunification Evaluation Project. Final Report, January 2004. SOE2-CT98-3081 http://improving-ser.sti.jr.it/default/page.gx? app.page=entity.html\& app.action=entity\& entity.object=TSER---$\underline{0000000000000563 \& \text { entity.name }=\text { Report. }}$ 
Concerning the rights of children under family reunification policy, the question of who is a child and, conversely, who is a parent, has been debated at length. In some cases, the identity of the parents is unknown; in others, such as cases of suspected child trafficking, the parents may be declared inappropriate caretakers. Not long ago, the word "parent" had a straightforward "biological" connotation in Western circles, as referring to a "natural" or "birth" progenitor, though adoptive or foster parents could qualify with proper documentation. Now there are growing debates on how to define a child if a substantial amount of time has elapsed since the parent and child were understood to have a filial bond, or when the "biological parent" could be the egg or sperm donor or a surrogate "womb" mother. Even in "standard" cases, problems have arisen when adults who claim parental or guardian connection to a child could not produce sufficient evidence of this connection, whether through birth registration documents, court records, or (in recent years) DNA reports, or could not meet the requirements for income level or accommodation facilities stipulated by state policy.15

As if the question of family relationship were not enough, there is the matter of who, exactly, a child is in the chronological sense -- and I am not talking here about the well-known disregard of so many Africans for chronological age. The point instead is that family reunification policies themselves render age a major point of contestation, arguably creating as much ambiguity as they do clarity. Most countries define a dependent child as an unmarried person below the age of 18. Hoping to pass as a chronologically defined child, however, many "unaccompanied minors" who have come from North Africa to Spain have failed bone density scans instituted to distinguish children from adults, along the 18-year line, and been sent back to Africa. The question of who is a child takes its most useful comparative edge, however, against that of who is a wife. Most family reunification policies hold that children must be less than 18, and the spouse must be 18 or older. UN documents, however, define a child as a person under 18 unless national laws recognize an earlier age of majority, allowing, for example, for marriage of adolescent women, who are thus treated as adults. The ensuing debates can be extremely divisive, revealing that even a notion as apparently "straightforward" as chronological age is inevitably surrounded by ambiguity and dispute in practice. This is especially true in situations in which immigrants must report or even shape their lives in ways to accommodate the legal strictures they face. Complexities like these set the background for a closer look at the role of family reunification policy in Spain. I should stress that the sources cannot tell us whether individuals came to Spain because of family reunification programs or independently. Still, a sense of the specific lines they set up are essential to apprehending both the demography and the anthropology.

\section{Immigrants and family reunification policy in contemporary Spain}

Spain's configuration of family reunification policies, while conforming to the basic EU structures, has arisen against the backdrop of its recent history as well as its geography. As one of the most formidable colonial powers in history, Spain generated centuries of migration, through commerce, conquest, education, and missionization, to the New World, Asia, and the rest of Europe. Well before the twentieth century began, the country became a labor exporter, its economy, largely agrarian, deflated by the loss of its colonial holdings. Scholars of Spanish migration history have traced Spain's dramatic transformation from a "sending" country to a "receiving" one, during the last quarter of the twentieth century, to several things. Most pivotal was the demise of dictator Generalissimo Francisco Franco in 1975. With Franco's death, manufacturing, tourism, industry and large-scale agriculture opened up, and with them, a demand for low-cost labor. At the same time, Franco's deeply conservative Catholic policies had banned birth control and divorce, so the end of these bans also sparked a decisive drop in fertility. From a Total Fertility Rate of 3.0 in 1964, the TFR declined to 1.4 by 1994 (Miret 2000). To add to the labor crisis, young Spanish citizens, now gaining more education, much preferred skilled jobs and life in the urban and industrial areas. By the time Spain entered the European Union in 1986, its farms and businesses were actively seeking labor particularly for unskilled jobs in

15 For an illuminating discussion on the Netherlands, see http://www.crin.org/docs/resources/treaties/crc.35/Netherlands_Coalition_annex.doc. 
manufacturing and farming.16 To fuel this booming economy, Africa has offered a ready source of low cost labor. For Africans, Spain has become a key destination because of its geographic proximity, low costs of living relative to other EU countries, and jobs opportunities, as well as its value as a transit point to the rest of the EU. Most African immigrants in Spain come through illicit means, many hoping to regularize their status.17 Undocumented workers, however, tend to work in arduous, underpaid, precarious agricultural jobs, moving from one seasonal job to the next.

The plight of immigrant workers and their families in Spain has drawn a mixture of antipathy and concern. In 1985 the country enacted its first major law on migration policy: the Ley de Extranjería, the Law on the Rights and Freedoms of Foreigners in Spain (http://www.migrationpolicy.org). In 1996, an amendment to the law recognized that foreigners had rights to education, equality, and legal counsel, and it established a permanent resident category. This amendment also incorporated an allowance for family reunification ("reagrupament familiar") for a worker 18 or over with a valid job contract. Such family members include a spouse 18 or over, any dependent children under 18 years old, and dependent parents of legal immigrants, with proof of relationship that the immigrant is supposed to provide.18 The implementation of these accords, however, has been uneven. While spouses are in theory allowed to join legally employed immigrants, for instance, the loss of this contract can shortly require the family to leave. Moreover, there has been a 5year ban on employment for an immigrant's spouse brought legally through reunification. Such measures largely seem to have increased participation in a thriving underground domestic economy among women who engage in low-paid labor in cleaning, caring for children and the elderly, and so on (Kaplan Marcusán 1998; Sow 2004a, 2004b), which further render them vulnerable to deportation. Finally, Spain, with its need for both labor and contributions by employers to its social security system, has offered several amnesties in the last two decades. The last, and most comprehensive, ending May 7, 2005, granted nearly 700,000 employed workers legal residence,19 and, with it, the right to travel in and out of the country. However, the fact that amnesty for immigrants and their dependents was tied explicitly to a worker's job contract has reportedly intensified the vulnerability of women and children to being sent home by some wage earners, who now had to uphold a more official presence.

Gambians were among the first Sub-Saharan immigrants to arrive in Spain in the post-Franco era, the original group having come as unskilled agricultural workers from rural eastern Gambia (Kaplan Marcusán 1998, Farjas 2002). Nowadays, Gambians who are educated tend to go to the U.K. and elsewhere in Europe as students and skilled workers (Rodríguez García, 2004), but most of those who continue to come to Spain are drawn from many of the same rural networks as before. In Spain, they are a group of modest size. As of Jan 1, 2005, municipal registry data compiled by the Instituto Nacional de Estadística showed 15,745 Gambian nationals in Spain and 11,548 individuals born in The Gambia (www.ine.es). This is surely an underestimate, however, since many Gambians (like members of many other African groups) are undocumented.20 They are concentrated into just one of the country's seventeen Autonomous Communities: Catalonia (population nearly seven million as of Jan 1,2005), in the far northeast of the country.

16 In the northernmost Autonoma of Catalonia, for example, a number of organic farms and commercial invernaderos, greenhouses, have sprung up to grow food and flowers for Spanish cities and for the EU market just across the border. See Cabré (1999) for a description of the dynamics of reproduction in urban Catalonia. For discussions of immigrant dynamics in urban Catalonia, see Domingo et al. (1995) and Domingo et al. (2002). For discussions of immigrants in the surrounding comarques, see Domingo and Brancos (1996), and on Spain, see Calavita 2005). For Africans in Spanish agriculture, see Hoggart and Mendoza (2000), and on Gambians in Spain, Rodríguez García (2001, 2004) and Kaplan Marcusán (1998, ms.).

17 http://www.migrationpolicy.org/news/2002 02 22.php

18 http://www.geocities.com/CapitolHill/Parliament/4327/ppascr16.htm, accessed March 6, 2006

19 A number of registrants were said to come from other parts of Europe, seeking the legitimacy that would allow them to live and travel within and out of Europe, by Schengen terms, and leaving as soon as they obtained it.

20 See Recano-Valverde and Domingo (2005) on a technique for estimating such numbers in Spain. 


\section{Social reproduction in West Africa and the emergence of "Gambian Spain"}

So far, I have presented a top-down, somewhat "Western" picture, of the immigrant situation in Spain. Indeed, although it is easy to assume that the forces of assimilation as well as the heavy hand of a bureaucratic Western state erase cultural difference, African immigrants in Spain find many ways to make it their own, making it mandatory not to understate the character of the home context. Even more important, perhaps, is the need to avoid simplifying immigrants' continuing social relations with it. Keeping such things in view, along with the evolving nature of family reunification rules, brings to light more subtle implications for marriage and reproduction. To make the case that family reunification appears to divide as well as to unite African families, I need some better handles on West African notions themselves of family, or, more accurately, "social reproduction," and the forms of political incorporation that have classically framed it. For this I will focus on the dynamics of marriage and political patronage, especially in African "frontier" settings.

In West Africa, numerous domains of social and reproductive life -- marriage, the production of children, the founding and settlement of a political frontier, and so on - are key modes of "circulation" across space.21 Women have classically seen children as key to security in the husband's home and a bulwark against competition from present or future co-wives and marry soon after puberty. Those in rural Gambia typically move to the home of their husband and begin bearing a series of children for him at a pace that will not jeopardize the health of their children or themselves. Maintaining such bodily formed means of spacing may require a woman to return to her mother's home to bear and wean a child, and to return when she is ready for a new pregnancy. At some point, however, and regardless of her chronological age, a wife becomes physically "spent" or "old" from her reproductive ordeals, with each subsequent pregnancy entailing more health risks. The husband who, out of gratitude for the woman who has aged on his behalf, should allow her "retire," acquiring a young co-wife for her, so she can begin a life of comfort and respect, or even allow her to return home to her own family, if she desires. Jealousies among co-wives and charges of male favoritism can be sources of bitter tension in polygynous households (Clignet, 1970, Randall and LeGrand 2003, Lardoux and van de Walle 2003), and a man may use his wife's "aging" as an excuse to marry a new woman. But a husband who does not bring home a new co-wife to take over the productive and reproductive burdens for a faithful wife who is worn out from childbearing may come home one day to find she has gone out and secured one for him anyway.22

Men move as well, of course, most notably to look for work, especially when it is time to marry. Young African men often leave home for long periods to work for bridewealth to secure rights to a woman's labor and reproduction (e.g., Enel et al. 1994, for the Joola of Senegal). Among the most important forms of male mobility, however, is that of founding a cultural and political frontier, a theme emerging vividly in African oral and written histories (Kopytoff 1987). In Liberia (Murphy and Bledsoe, 1987), oral histories of a polity typically depict a first-comer/founder's act of exploring an unknown new land, securing it from enemies and dangerous ritual forces, renaming it to symbolically establish his control, and clearing it for farming. Acquiring a wife to work on the farm and bear children, this founder begins to strike allegiances with newcomers who seek security as he once did and assigns them territorial sub-domains to administer. Giving them one of his daughters or sisters in marriage, or that of a client, he creates, through their ensuing generations, a perpetual matrilateral line of subordinate "nephews" or "newcomers" to himself and his

21 For more on "circulation" and the political establishment of a cultural frontier, see Bledsoe, Houle, and Sow, ms.a; and Bledsoe and Sow, ms.; and Murphy and Bledsoe, 1987).

22 See Bledsoe 2002, on the intertwined politics of polygyny and aging. Polygyny and the movement it precipitates continue even among highly educated urbanites as facets of family prestige and desires to forge patronage ties. Rates of polygyny appear to be declining in Africa, and a number of countries have formally banned the practice. But so powerful remain the forces that support it, that sub-rosa polygyny such as informal plural unions among residentially separate partners, "serial monogamy," and the acquisition of young partners by "sugar daddies," continue to flourish across the subcontinent and, as I will see, into Europe (see also Sargent and Cordell, 2003). For some examples, see Locoh (1994), Comaroff and Roberts (1977), Dinan (1983), Parkin and Nyamwaya (1987), Sargent and Cordell (2003), and Fleischer (2005). 
original "uncle" or founder line. In later years, subsequent newcomers may in turn be placed under the jurisdiction of each original nephew. Receiving sub-domains to further consolidate from such a nephew, all become adjunct members, through marriage and protection, of the "founder" hierarchy. In what can be the most dangerous of situations, then, chains of support can consolidate nested political structures knit together through the idioms of marriage, kinship, and patronage.

In Spain, all this would appear to change. Many Gambian immigrants see Spain in the long-term: a place to work, gain residency, and raise a family. Like many other Sub-Saharan Africans, they also entertain the yetmore long-term hope of returning to Africa when they retire. Sending home remittances and making visits, when possible, are intended both to help their families and to ensure a warm welcome from supportive kin after work life is finished. The hope of returning to a life of honored retirement, however, is often a myth that the harsh realities of immigrant life make impossible to realize (see Kaplan Marcusán 1998:179-81; and Rodríguez García 2004:72-73). With the EU tightening its borders, undocumented Gambians who before could have traveled easily between Africa and Spain face treacherous crossings over the Straits of Gibraltar, border controls, exorbitant expenses, grueling living and working conditions, and minimal competence in the language and practices of the host country. Many relate a convoluted employment history of precarious, erratic jobs patched together across Africa and Europe, earning barely enough money to stay out of debt, much less send home regular remittances or bring a wife from Africa. Marriages appear to occur largely through arranged unions through family brokers back home. Still, with a high adult gender imbalance among eligible conjugal partners in Spain, Gambian men frequently find themselves in dispute over women. For Gambian women, who typically come through reunification, there are reports of forced marriages, 23 "white marriages" (on-paper only), spousal abuse, and conflicts with unwanted co-wives (Sow, 2004b), Gambian children, to the intense frustration of Spanish school officials, often move when their fathers take jobs elsewhere (Farjas 2002) or go back to Africa for extended periods to see relatives, and failing sometimes to return. 24

Culture inevitably changes, but longstanding cultural models, together with the social ties from Africa that continue, can provide the foundations for stability in entirely different contexts. A patron-client structure based on the notion of a new political "frontier" may emerge not just in unexplored, untouched lands, but in fully inhabited and named urban areas with complex social orders and deeply entrenched histories (see Barnes' account, 1987, from a highly urbanized area of Nigeria). Indeed, what one sees in Spain is that an immigrant who becomes established himself becomes a patron ("elder," "firstcomer," "uncle," etc.) to those who come later, and for them he may mediate papers, wives, and jobs. Idioms of marriage, kinship, and territorial expansion and consolidation - all can be used to forge security in new "immigrant frontier." 25

\section{The demography of family reunification in Spain}

How might such extractions from the African ethnography be brought to bear on the test of family reunification in Spain? Complications wrought by kinship terminologies -- which are after all cultural symbols of social relations -- are just part of the picture. As we will see, family reunification policies themselves can offer severe challenges. The following numerically based account begins with Africans as a whole.

23 The phrase "forced marriage," which Gambians themselves use even in The Gambia, can be misleading in literal translation. Some of these are simply family-arranged marriages between acquiescent partners.

24 Various observers report ethnic variation in these practices, with the Serahulli allegedly practicing more fosterage and more wife and child substitution than the Fula and Mandinka.

25 Similar patterns and their linguistic indicators emerge throughout Africa. In the languages of The Gambia, linguistic terms link superordinance with territorial precedence and with matrilateral kinship. In Serahulli, from eastern Gambia, hiiri means "old persons," "experienced persons," "firstcomers;" in Wollof, there is "diatigui" ("elders," "experienced," "firstcomers," "uncles") vs. "dahar" (“youth," newcomers," "latecomers," "nephews"). See also Sow, (2004a). 


\section{Citizens and foreigners in Spain}

The 2005 register shows a population of 44,128,530, of which 91.5 percent was of Spanish nationality, and 8.5 percent non-Spanish. Forty-nine percent of Spaniards and 53.1 percent of non-Spaniards were male. Figures $1 \mathrm{a}$ and $1 \mathrm{~b}$ show age/sex pyramids for everyone in the register in Spain: Spanish nationals as well as foreign nationals. (In these charts, immigrants who have gained nationality are indistinguishable from people whose families have lived in the country for generations.) Men, in blue, are on the left; women, in red, are on the right. The hatching reflects foreigners.

\section{Figure 1a}

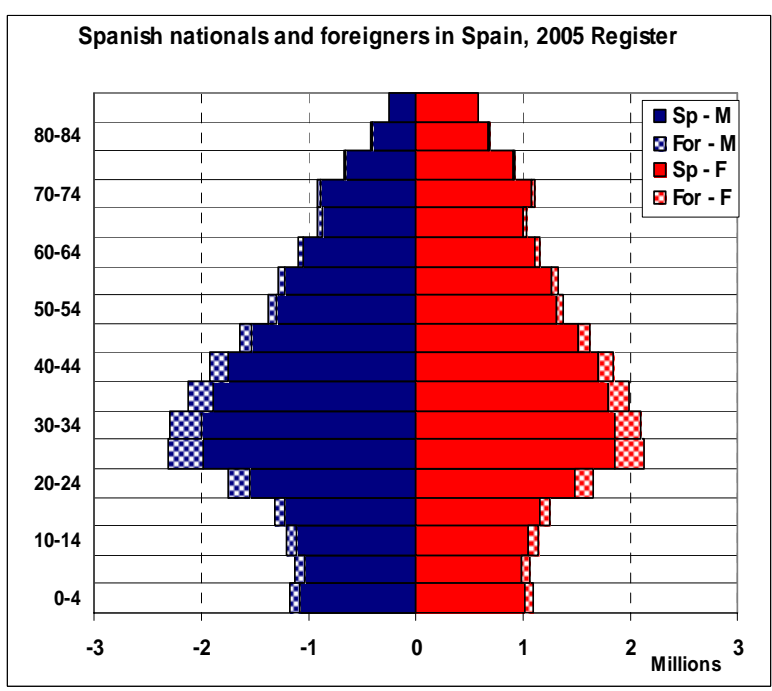

\section{Figure 1b}

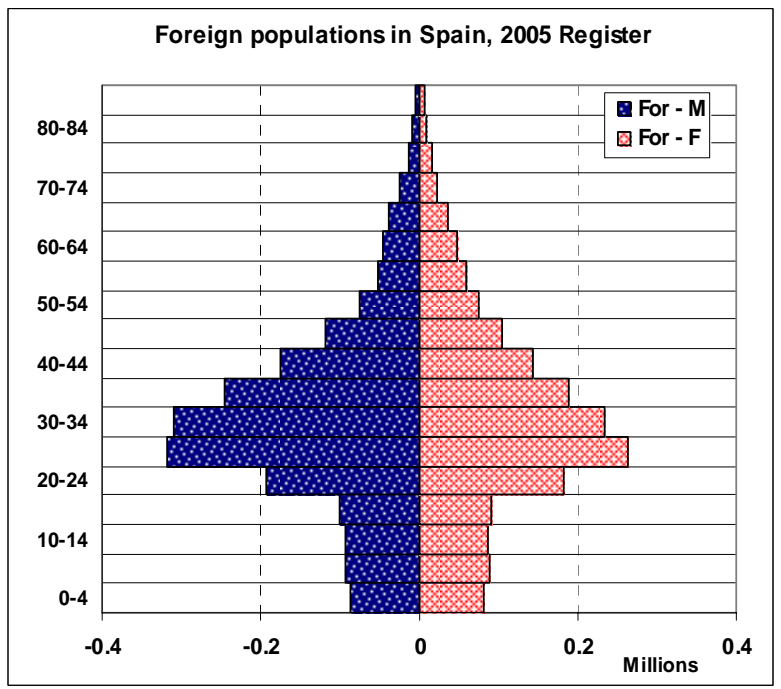

Figure 1a, reflecting the dramatic post-Franco fertility decline that began immediately after 1975, also shows that the great majority of registered people are Spanish nationals. Peering more closely at the shape of the foreigner population, Figure 1b expands the external edges of Figure 1a. Here we see the foreigner ranks dominated by the working age population, especially among men. For decades, Moroccan-born individuals have made up the highest percentage of immigrants in Spain because of the large supply of young male labor they offer. According to the 2005 register, Moroccans now comprise 13 percent of the foreigner population, though Latin Americans, especially Ecuadorians and Colombians, with many women coming as domestics, have been moving rapidly in the distribution. Among the aged are longstanding immigrants who have retained their nationality as well as a modest number of parents of immigrants who were brought under family reunification policy (see Escrivá, 2004, 2005). The ranks of the aged are also composed of a number of retirees from Britain and Germany and other beach-less climes of Europe who move to southern Spain and the Canary and Balearic Islands.26

Within these broad outlines, there is immense variation among immigrants in Spain, and none more so than among Africans. Except for the longstanding Moroccan and Algerian populations in Spain, most Africans in Spain represent very new populations, and most, when they come, take unskilled temporary jobs.

Accordingly, the sex distribution of Africans in Spain, as Figure 2 shows, is largely made up of men. (Note that included here and in subsequent census data figures are only those 2001 Census countries that later appeared in the 2005 register.) In the cases of countries like Mali and Senegal, some of these men may see themselves as temporary residents who are on their way to France, where both francophone nationalities are represented far more heavily than in Spain. The only exceptions to the "male" predominance among African national populations in Spain are CaboVerdeans and Equatorial Guineans. Equatorial Guinea is the only former Spanish colony in Africa and its national language is Spanish. Along with Cabo Verdeans, with their

26 For recent discussions of foreigner populations in Spain see Bledsoe et al. (ms.a, ms.b) and Roig Vila and Castro Martín (2005). 
Portuguese and what has been easier access to Spain, Equatorial Guineans now provide many domestic workers for Spanish homes. These populations also include children, of course, but not nearly the number in that for most countries we see in Africa. Spanish citizenship being difficult to achieve for African born individuals who wish to have it -- Spain requires ten years of residence to apply for naturalization, and even then, attaining citizenship is by no means assured -- the children of African immigrants are largely, like their parents, non-nationals.

Figure 2

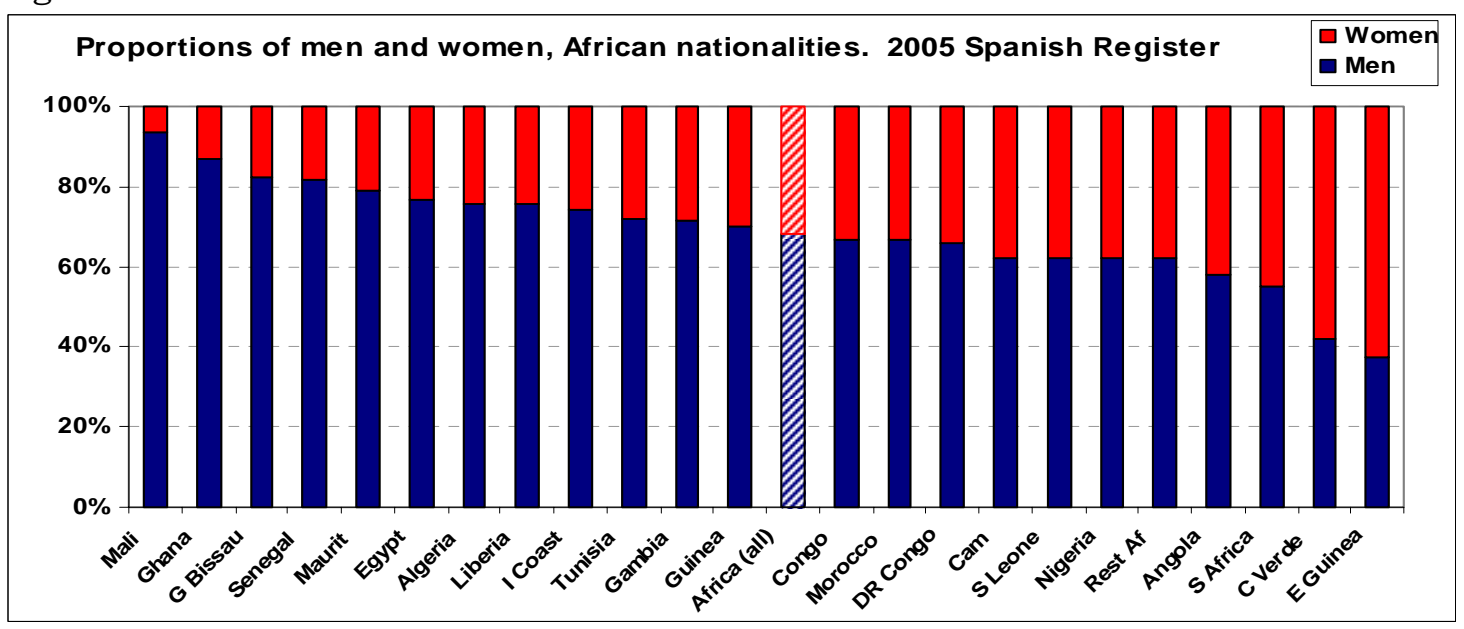

South Africans, with nearly equal proportions of women to men, deserve a special word for purposes of interpretation in this paper. If most South Africans in Spain are white, as I believe they are (all the other analyses I have done show that they closely follow the pattern of northern Europeans who live in Spain), their otherwise-odd numbers throughout will make more sense.

Family reunification and African women in Spain: Traces in the official demographic records?

Turning to marriage, one of the pillars of social life in Africa and among African immigrants in Spain, Figures $3 \mathrm{a}$ and $3 \mathrm{~b}$ below take (a) marital status among women of African nationality compared to non-African foreign women, and (b) African women compared to African men.

Figure 3a

Marital status of African vs. non-African foreign women 2001 Spanish Census

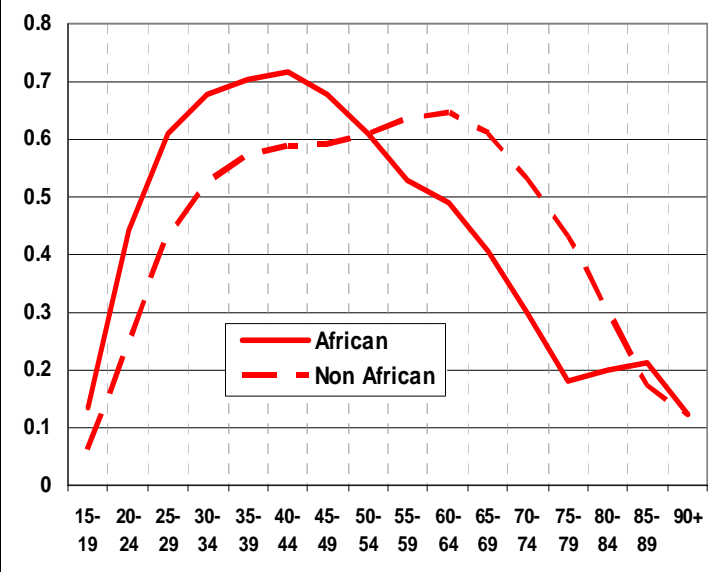

Figure 3b

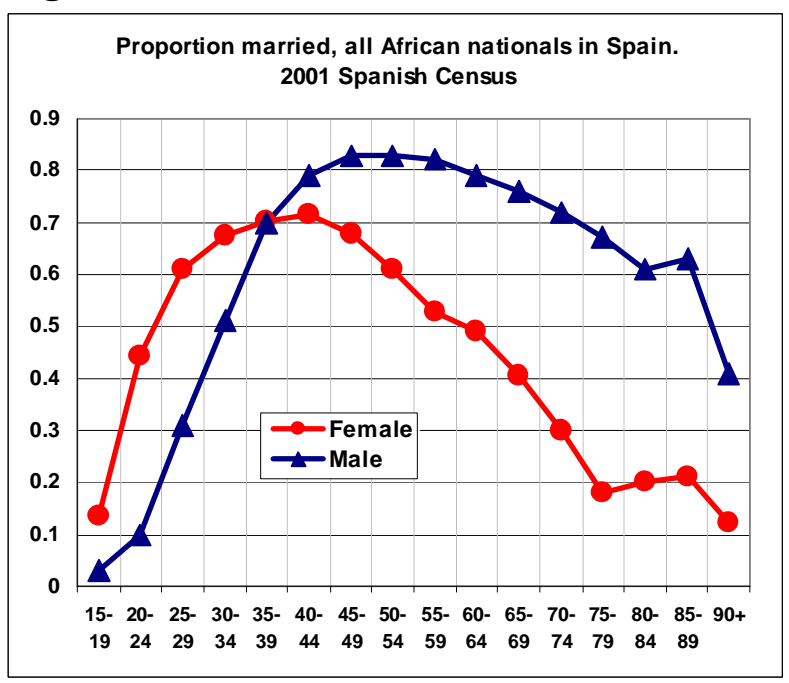


These simple lines, of course, incorporate a very broad spectrum: everyone from nurses and domestic workers to study-abroad students, wives of small-business shopkeepers, and retired widows. I have also included North Africans along with Sub-Saharan Africans, who constitute a heavy pull on the results. Whatever their limitations, the results show much younger levels of marriage by ages among African women than among other immigrants.

But while African women in Spain may be married younger on the whole than immigrants of other nationalities, women in their most reproductively relevant years from some African countries are married no more, and in some cases far less, than women from other continents. Figure 4 narrows the focus to African immigrants in the 2001 census, looking at proportions married by age group in the most "typically-married" African ages, compared to the "baseline" of non-African foreign women This graph is awkward to read, stacking up differences in proportions at each age group, rather than showing values relative to a whole. Though I excluded countries with N's of less than 20 in this total 20-year age range, the graph also introduces distortions from groups with low numbers; all countries' proportions figure equally. Still, the device suggests an enormous spectrum of marital variation among those African women immigrants who appeared in the 2001 census.

Figure 4

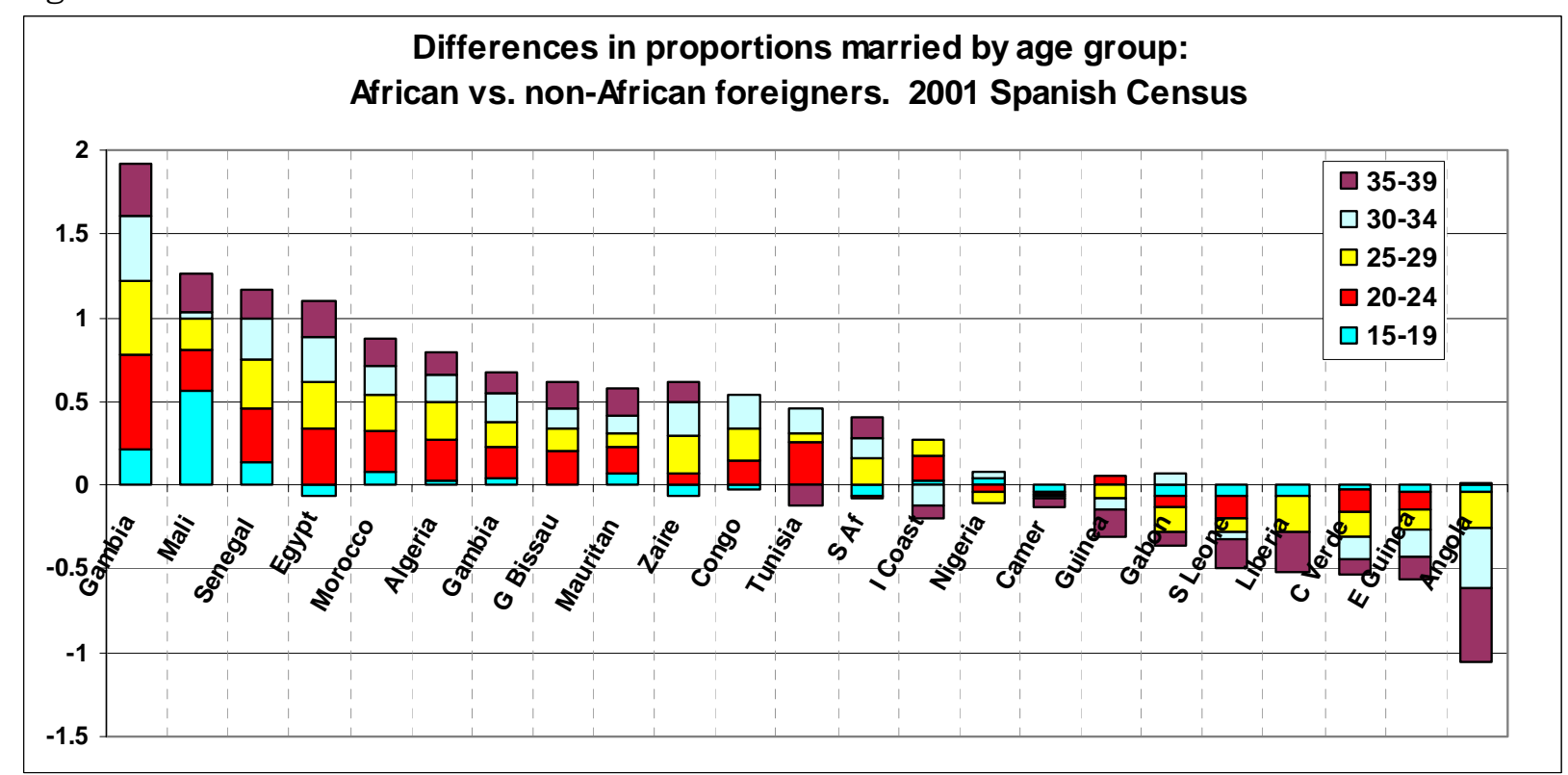

On the upper left portion of the marriage continuum are countries with what every source suggests are high rates of early marriage and high desires for family reunification for migrant male workers who can afford a wife. Gambians, my main interest, are highest in proportions married among this continent's highly married migrant groups, and they, like Egyptians, Moroccans, and Algerians, appear on the whole to have come specifically for marriage. I have included ages 15-19 in this graph to show the very young Malian married women who may be on their way through Spain, perhaps stopped temporarily, to enter arranged marriages in France. Beyond this point, however, the graph's numbers quickly begin to cascade, and on the "lower" and "right" portion is a very different constituency.

Here lie what I believe to be two groups. One consists of women who are most likely in Spain as domestic workers: Cabo Verdeans and Equatorial Guineans, whose low levels of marriage are perhaps unsurprising, given their independent employment in the country. The other group emerges immediately from the most superficial scan of any human rights web site in the world: women likely under high duress. This paper is about family reunification, but it can hardly overlook what already appear to pose some stark cases in which not only does family reunification appear to not be practiced, but not much else in the way of human rights 
either. Of them there appear to be two likely-related types. One includes women from the war-torn - as well as more distant -- regions of Africa (Sierra Leone, Liberia, Angola, and possibly Guinea, which has attempted to shelter thousands of refugees from its southern neighbors). The other comes from the countries most commonly reported in the Spanish and international press to have organized prostitution networks (Nigeria, Cameroon). Prostitutes are undoubtedly highly under-represented in such sources, and trafficked people, to the extent that they may exist, are unlikely to appear in them at all. As well, there is no telling who is "really" married and who claims to be in the official record. Nor can we be certain that many people have not tried to claim a nationality strategically (for example, Liberian, Sierra Leonean, Angolan), with the possible advantage such claims might lend to a refugee application in Europe. What we see here may thus be misleading. More likely, I believe, is that this chart, along with a number of other slices one can do, reflects the tip of a much larger iceberg. Whatever nationality women in this cluster "really" hold, they have very few children with them, and are proportionately unmarried, a fact that seems all the more significant for immigrants from a continent with such high female marriage rates. They also have likely come very far and under conditions of high political stress at home. All suggests that this group has probably not come under conditions that will allow them to make a "normal" living or begin a "normal" family in Spain, whether under conditions of family reunification or anything else.

Further suggestive evidence along these lines are charts like Figure 5, showing the ratios of four age groups of women to children aged 0-9. I include children at ages 5-9, not the child group of usual fertility interest, for a specific reason. Although immigrants just arriving in Spain may have small children either with them when they come or they may bear them shortly after, neither they nor people who are on their way to somewhere else, however, are likely to appear at the municipal registry to sign up many children of 5 to 9 for eligibility to social services. Here again Sierra Leonean and Nigerian women are on the very extreme end, especially among the ranks of 25-29 year olds, women who we would most expect to be having children. But we now turn our interest to nationalities whose women immigrants in Spain have very low ratios of themselves to children, and once again these are women of groups who most appear to be engaging in family reunification moves toward Europe on the grounds of conjugal relationship. Among them, Gambians appear to have recorded nearly twice the number of 0-9 year olds in the 2005 register as any other group. (See Farjas, 2002, for extensive descriptions of what school principals in several Catalonian towns have realized is a growing Gambian constituency of their school populations.)

\section{Figure 5}

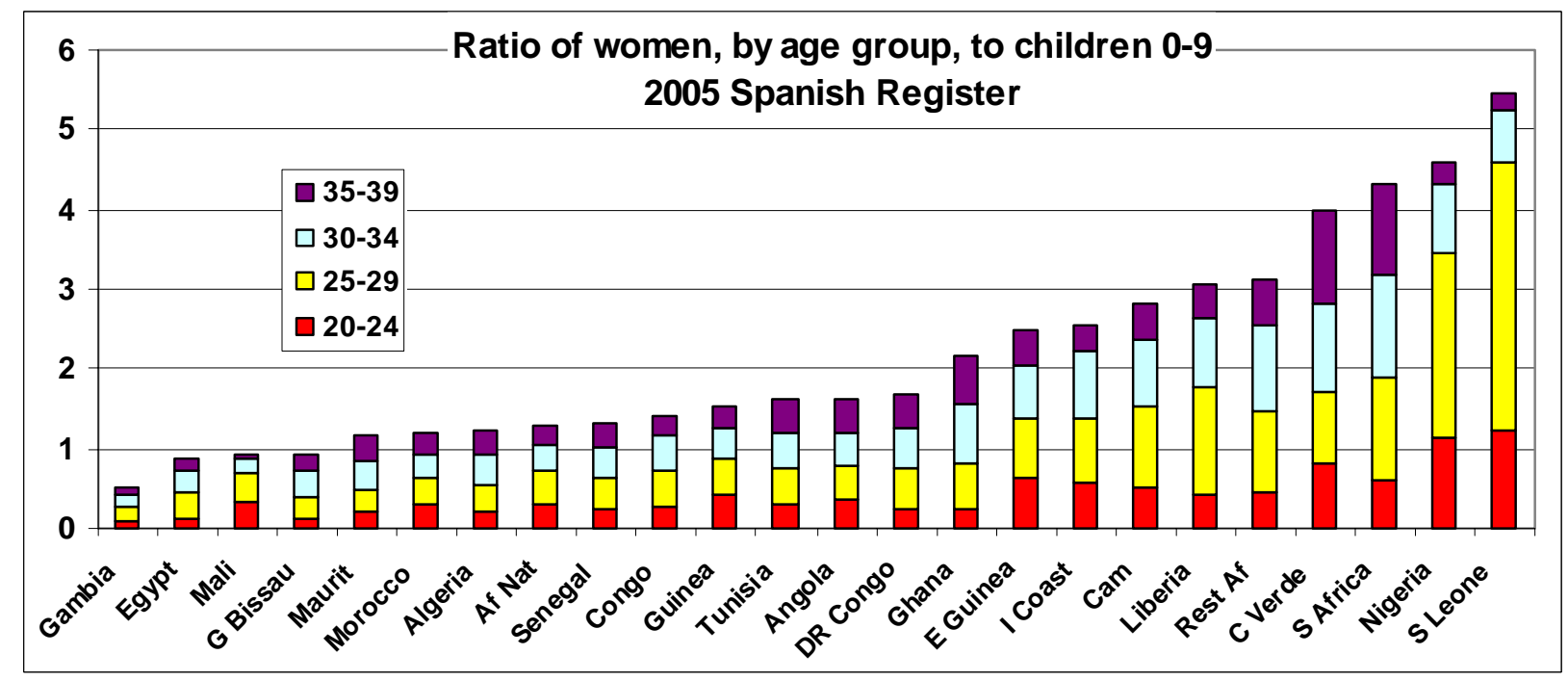

As noted earlier, the official sources do not allow us to identify parent-child relationships in households or among specific individuals. The 2001 census, however, did include information on broad age groups of children present in a household. Figure 6 shows the percent of married women aged 20-39 from several 
different countries who were living in a household with one or more girls under 15.27 Using this as an index, however primitive, of "family reunification," the following groups, chosen to represent the African immigrant configurations that began to emerge above, reflect a pattern that provides more direct household evidence on "settler" versus "stress" clusters.

\section{Figure 6}

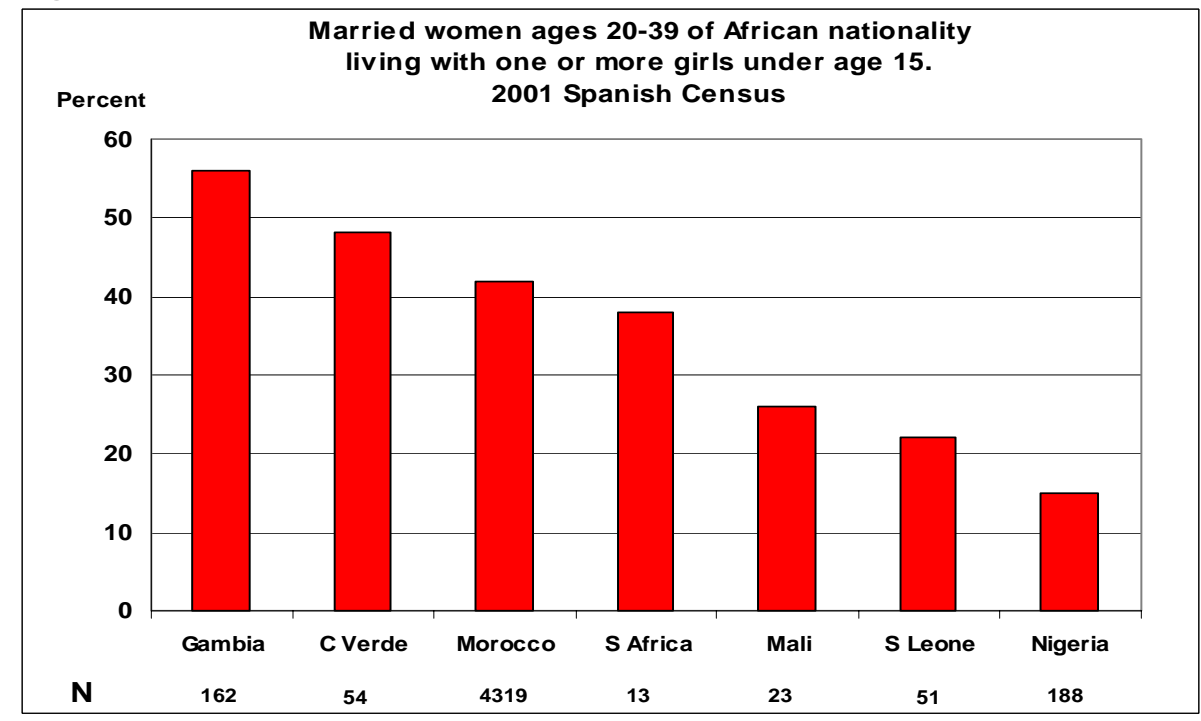

High fertility rates likely explain Gambians' and Moroccans' reports of living with one or more girls under 15. Cabo Verdeans tend to be older than other African women in Spain. As domestic workers they might have older children with them, or they may be living with a family who has a daughter under 15 for whom they are caring. Malians who appeared in the 2001 census were highly married but did not appear to have many children at the time. Only now, in the 2005 register, do we see a growing number of Malians with small children. Sierra Leoneans and Nigerians, if indeed they are more likely drawn into the life of sexual workers, show the smallest evidence, at least with this measure, of anything that might have been termed, even at this earlier point in time, family reunification. Even the probably-white South African women are living with more children than they are.

The results so far of these scans of the very wide range of Africans who appear in Spain have begun to point to some clear effects that we might expect family reunification rules to create, on who is brought and under what status from Africa -- or at least, again, how they must construe themselves for official reporting purposes. Women who appear in the official sources come for the most part at legal family reunification age ranges, but they appear to be brought just at the age when they are eligible to qualify in family reunification as wives. Young African women arrivals very much need to be seen as adults since most appear to come as spouses. Young men, on the other hand, since they rarely come as spouses, under the pressure of family reunification rules must be seen as "children." Everyone is attuned to the strict family reunification rules of chronological and civil status, but the impact on men and women is very different. Especially, I suspect, all this reflects the dilemmas of a group of marginal status whose claims to legitimate entry are narrowing sharply to the idiosyncratic claims of family reunification.

27 Since the internet version of the census makes it awkward to create a variable that would compile boys and girls under 15, I chose to look at girls as likely children of the women in the household, on the grounds that they are probably not old enough to be wives and that they probably would be more dependent than boys who might come as young as 15 for work. 


\section{Gambian "settlers" and Spanish family reunification policy}

Orienting now to Gambians in Spain, we will begin to look particularly for evidence of "settlement" efforts among this long-standing immigrant group. Figures 7a and 7b, from the 2001 census, show marked patterns that the logic of family reunification could accommodate, and might indeed expect from a [non-white] African group in Spain. Figure 7a, reflecting all Gambians in Spain irrespective of where they were born or their arrival date, shows that by age 20, 80 percent of women are married; by 25,90 percent are married. We do not know from the census where a marriage may have occurred or to whom, but the reported marital status of even the youngest of marriage-eligible women is sharply different from that of Spanish women, who marry on average at age 27.7, one of the highest in the world for women (for men, the average age is 30 ).28 To gain more precision on the relationship of marriage to migration, Figure $7 \mathrm{~b}$ uses the numbers of Gambian nationals who arrived within the last nearly- 5 years prior to the census. The jump particularly among 20-24 year old married women implies that the recent groups of Gambian women in Spain were sent almost as soon as they were eligible for marriage, and that they married shortly after they arrived. For Gambian men, given their far greater numbers than women in Spain, some of those who report themselves to be married are undoubtedly married to women back home. At any rate, for those Gambian men whom we see in Spain, it is only when they reach their early thirties that half are married, equaling the high marital proportions of the female nationality counterparts only at age 45 .

Figure 7a

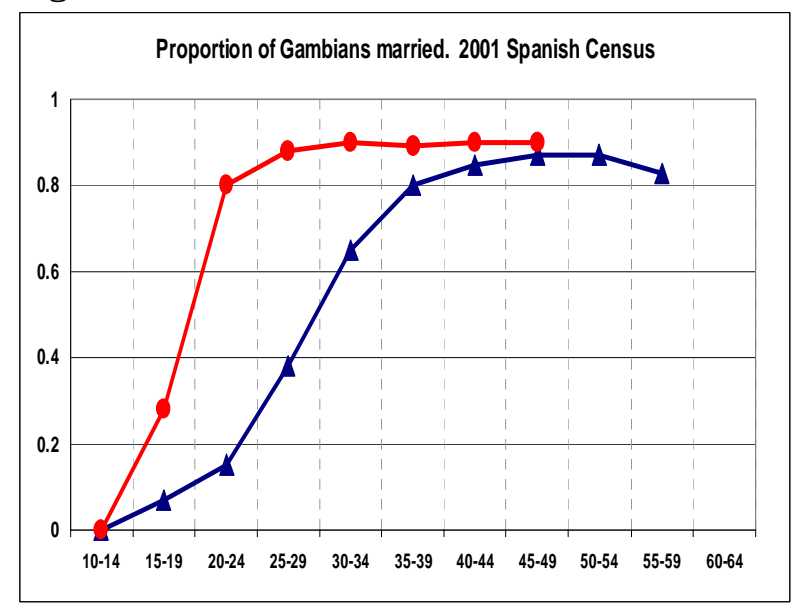

Figure $7 b$

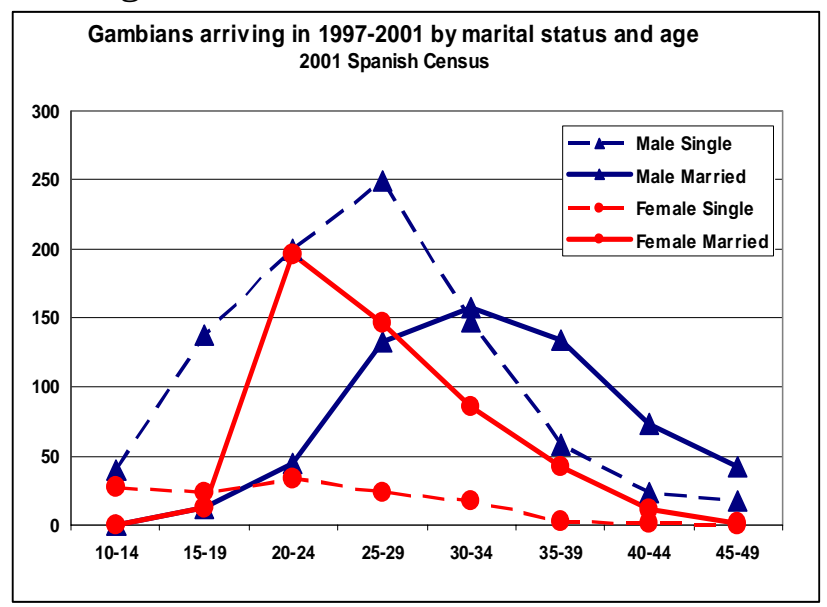

We must be careful not to assume that these thin slices of Gambian marital life depicted for Spain, especially those shown in Figure 7b, represent any sort of continuity in a single individual's life course, in so far as people come and go from Spain. They do not necessarily represent "normal" life either back home or in Europe. We must be equally careful to avoid assuming that the people who are depicted in these

"nationality" categories, if they are indeed married, are necessarily married to each other or to anyone in Spain at all. Nonetheless, the figures, against the background of readings from the ethnography and my own work, seem to show very different stories for male and female migrants. Gambian men, who start coming to Spain for work in their late teens, are not only unmarried but appear to remain so for some time, probably later in many cases than their counterparts back home. Gambian women who come to Spain, like many other women from the northern and Sahelian zones of Africa but very unlike African men, appear to come specifically for marriage, and at the most minimally allowable age for marriage under family reunification rules. They also are married more often at young ages than their peers back in The Gambia.29 Because nearly all female Gambian nationals in Spain of this age were born in The Gambia and not in Spain, the results

28 http://www.ewtn.com/vnews/getstory.asp?number $=67784$

29 In the 2001 Spanish census, 28.3 percent of 15-19 year old women were married, as were 80 percent of 20-24 year olds. According to Sonko (2006), the 2003 Gambian Census showed twenty percent of 15-19 year old women married and 57.5 percent of 20-24 year olds married. 
almost certainly reflect the presence of many young women who have reached the age allowed by Spain's minimum marriage age laws and have come under family reunification packages.

These charts point to a pattern of high consonance with marriage family reunification dynamics, but they cannot tell us how family reunification rules may affect particular individuals, or at least how they report themselves. Since family reunification policies, in combination with national laws, draw some very clear legal lines centered on age, the boundaries of age limits on children and, conversely, spouses, themselves would be a good place to look for more solid evidence. What ages might draw particular concern, and under what conditions might people try to adjust their ages to qualify for the "safe" side of an age boundary? The answer in the cases of both men and women appears to be "18," but which side of that number one appears to lean toward is quite different for the genders. To better frame this, we must return to the spirit of the story I told above, of patronage and settlement in a new political frontier.

Who is a wife, who is a child? $20-24$ year old women, and 17 year old boys

Taking the census of 2001 (the official date was Nov 1,2001), Figure 8a moves in for a very close-up look at age in an individual year. Its numbers show the raw numbers of men and women who say they arrived in Spain in 2001: within roughly the last 10 months. The Gambian individuals by single-year age are impossibly small numbers for any serious statistical purpose, but provocative nonetheless. Broken down to catch these two very small windows on time, they first show a clear elevation in very recent immigrant women who are reported to the census takers as being age 20. This may well reflect the effects of simple numerical rounding among people who are uncertain of their age. It may also reflect attempts to conform to Spanish restrictions on bringing women younger than 18 as wives, or to choose a wife from an available pool of women who are old enough to qualify under the terms of family reunification to come to Spain. But I am also reminded, when I look at this chart, about what some interlocutors in Spain suggested, quite independently, to be efforts by Gambian families to report incoming brides, who may be quite young, at a comfortable distance from 18 to avoid arousing official concern that they might be "children."

Figure 8a

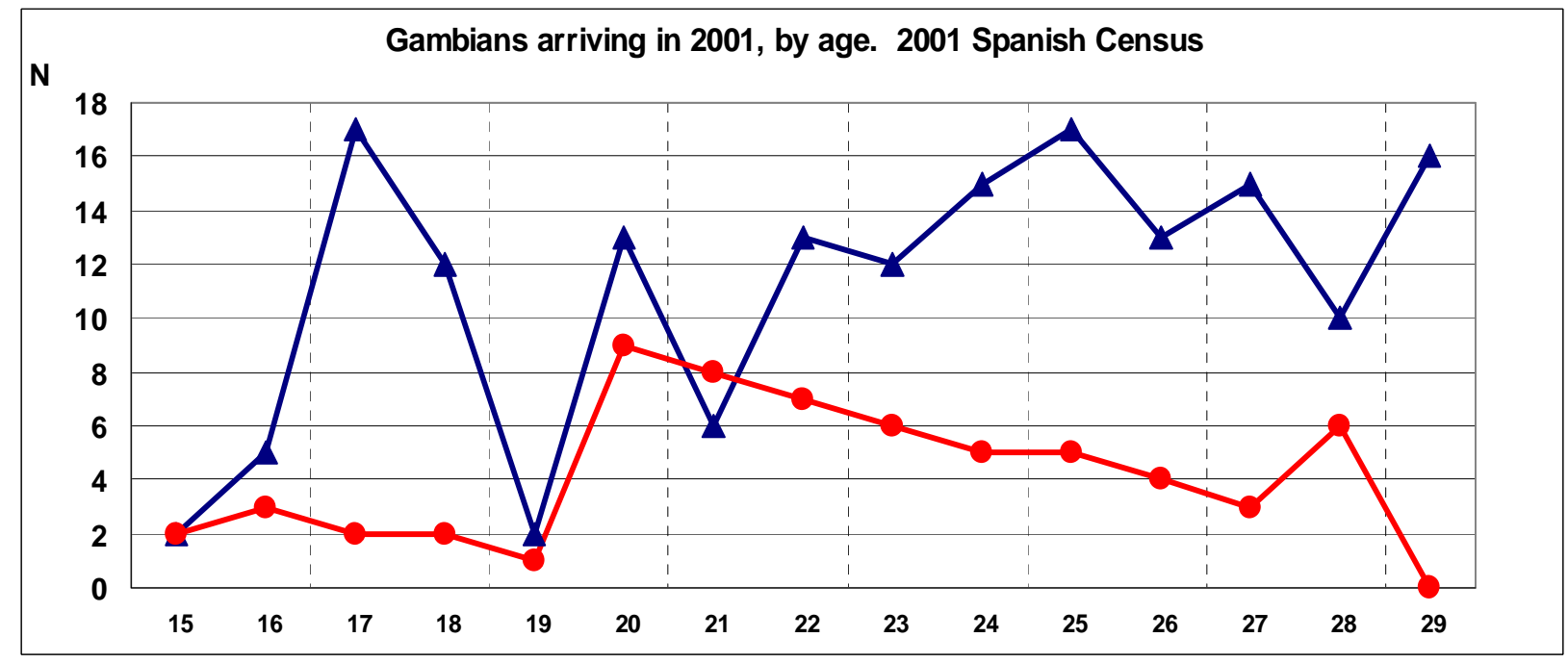

For Gambian men, Figure 8a very likely reflects an "age effect" of family reunification as well: not, however, as spouses, but as children. Men's ages show an unsurprising heaping effect at 20 as well. But the by far most striking feature of this chart is the very odd spike in male ages at 17. The drop at age 19 may well reflect a rounding off by people who are uncertain of their age; and 20, after all, is lying just ahead. With 18 being the age of legal majority, however, and the point at which youth can no longer qualify as minors in family reunification packages, the "17-year old Gambian boy" effect, one suspects, reflects efforts to take advantage of, rather than be caught by, the available repertoires of temporal boundaries to report immigrant youth who 
came under a family reunification application as children.30 Certainly this line shatters any temptation to attribute all heaps as a tendency of unsophisticated, illiterate people to round off their ages.

This chart, in sum, appears to reflect pressures wrought by family reunification policy to edge young males toward childhood, and young women toward adult status. For either, of course, we may be seeing "legality": boys brought from The Gambia at the last available moment of legal childhood; girls brought at the earliest possible moment of legal marriage. Regardless of whether one believes this scenario or one that posits strategic reconstructions of age to get the public record "right," these reports suggest a tiny but consistent edge of a "settler" effect - people actually trying to stay -- for members of the Sub-Saharan population with the deepest roots in post-Franco Spain.

Certainly the young women and boys of any world region could be showing these patterns, though, and hindering any attempt to pursue the 17-year-old-boy phenomenon more broadly, at least until the 2011 census arrives, is the paucity of such numbers among nearly all African nationalities whose members fall within this analytical slice. I should make clear, also, that while Senegal, Algeria and Ghana showed a slight dip in the number of 17 year olds, no other African nationality's reports of its 2001-entering cohort of 17 year old boys come close, in its proportions, to that of young Gambians. What makes me think these numbers may indeed be reflecting the lively traces of a population attempting to settle in Spain are some further hints.

\section{The volatile age: 17}

Given these results for Gambians, one can step back and look at the African countries that sent young people to Spain in 2001. Those who sent ten or more in 2001 are shown in Figure 8b. I exclude Moroccans, despite their far greater numbers than all the groups put together, since most are on an entirely different trajectory.31 Figure $8 \mathrm{~b}$ shows that among young African men, 17 was a noticeably popular age to be, while 18 was not. In this graph, the female pattern emerges strongly as well. For them, 17 is not a preferred age, while 18 marks the resumption of a "normal" increase that we might expect for young women coming for marriage under family reunification policies.

30 The figure shows a number of 18 year olds as well who said they arrived in 2001. Since the census was conducted 1 November 2001, most would have reported themselves as 17 when they came. Since there are almost no 19 year old men (who would have been 18 when they came), these youth may have been trying to avoid being classified as "adults" when they came - better to say 16 than 17 , perhaps, to arouse suspicion.

31 For young Moroccan boys and men, most efforts to come to Spain would have happened earlier, when many began to come as "unaccompanied minors" who sought entry into the Spanish child protection system where they awaited 18 , the age of legal majority, when those who were allowed to stay were given papers and allowed to register for the first time. 
Figure 8b

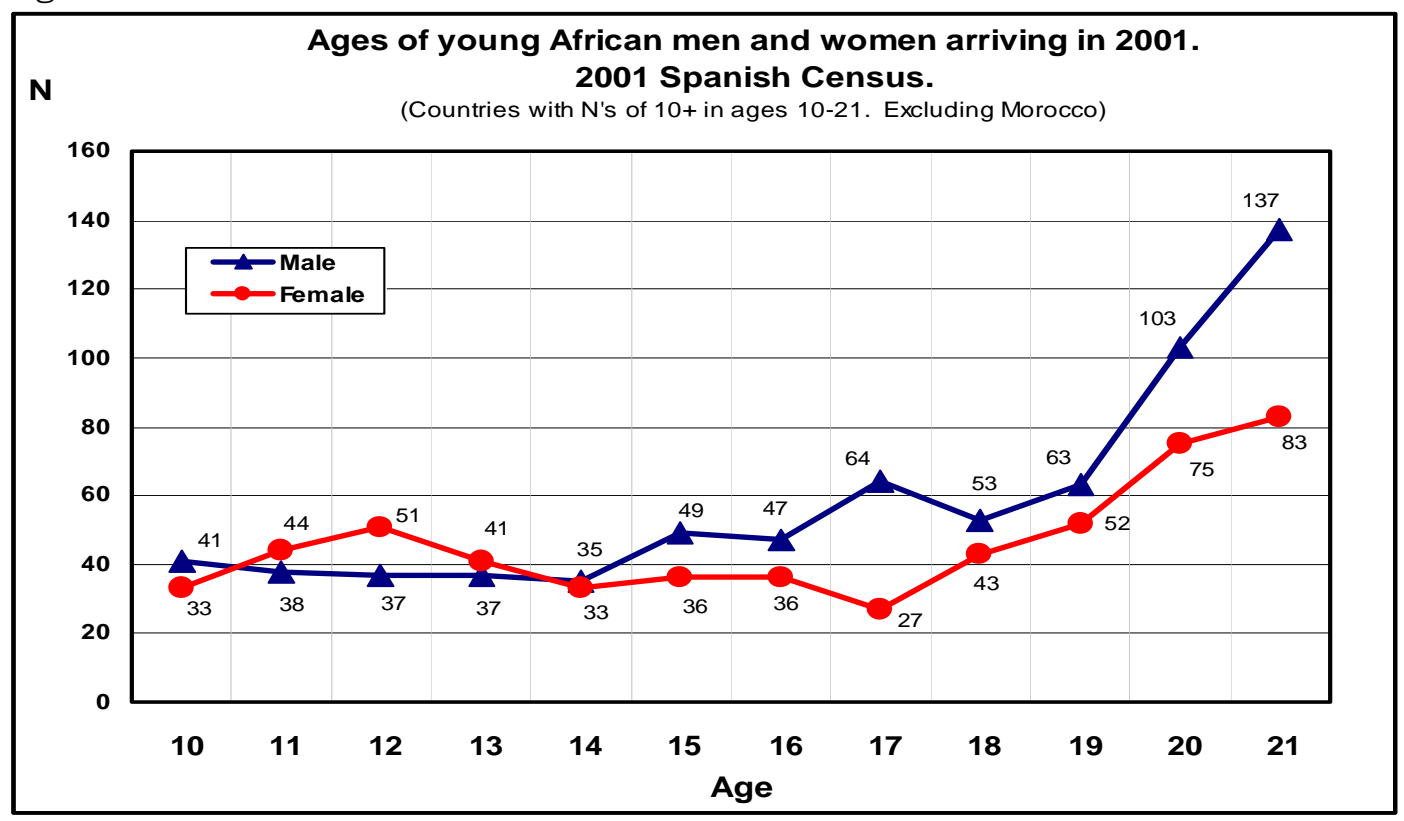

From circulation to substitution: Gambian family reunification slots in Spain

If "circulation" models of marriage like those described above for West Africa may stretch demographic ways of thinking, then the tensions that family reunification policy creates in conteporary Spain stretch them even further, and none more so than those created by polygyny. Denominators are a perpetual aggravation. But if this assessment is right, and if Gambians are the Sub-Saharan African group who have been working the longest to establish families in Spain, the numbers may help us to detect traces of family reunification policy's impact on mother-child ties on this group, whether it unifies or separates, at least as measured by coresidence. To consider this, we must bear in mind the principle that allows minor children in multiple numbers to be unified with either parent, but limits the definition of a legal spouse to just one.

With the risk and expense Africans face in both trying to bring family members and for family members to return to Spain if they leave the country, the "slot" approach, explained earlier, appears to be the best way to secure any hard-won position that individual dependents create.32 That is, the Gambian model of social reproduction in Spain appears to be pressed from one of fairly routine circulation of people toward one of substitution, while families tend to adopt an "accumulation" strategy for children and a replacement or "substitution" strategy for women. What clues might the official Spanish census and register yield on the conundrums surrounding social reproduction for West African immigrants in a family reunification regime that demands legal monogamy? What evidence might we have of their resolutions? None of the official instruments asked questions on polygyny or on undocumented status. They certainly had no "African" dilemmas in mind. Nonetheless, a look at close scrutiny of these sources suggests some surprising answers. I look first at children.

Figure 9 shows differences among Gambians in Spain by whether they were born in The Gambia or Spain. Solid colors represent individuals born in The Gambia, and hatching reflects those born in Spain. The figure shows a very large number of older men, up to age 49, an unusual feature for a Sub-Saharan group in Spain, likely indicating a longer residence in Spain for men who came as laborers. Given the length of time that

32 An apocryphal story from Germany describes the wonderment of German statisticians specialists at the very high longevity of Turks. Eventually it was realized that the passports of many of those individuals still on the books as "living" had long since died, while their passports were now circulating among undocumented kin. 
male Gambian workers as a group have been in Spain, the results also appear to testify to the difficulty that African nationals have in attaining Spanish nationality. The most distinctive attribute of this chart, however, is the presence of so many Spanish-born Gambian children. How are we to account for this large number of children? Is fertility among Gambian women in Spain really this high? If not, who are all these children?

\section{Figure 9}

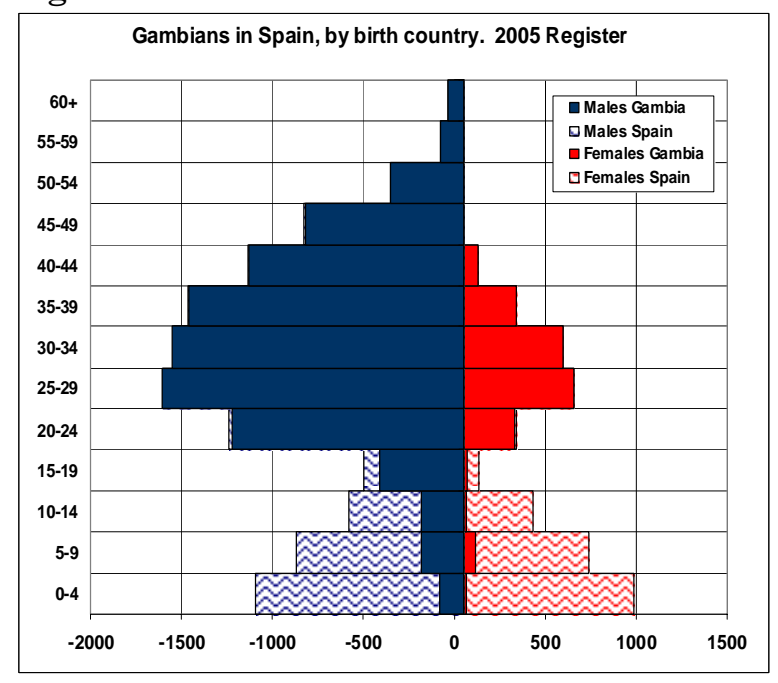

According to some sources, some of these may be foster children -- the children of parents who are not living in the household - who circulate into the households of caretakers, much as do their counterparts in Africa.33 Strictly speaking, under Spain's current family reunification policy, such cases of family reunification would not be allowed, though there may be cases of foster children who are claimed as biological children so that an adult member of the household can maintain his/her prior caretaking responsibility or simply to get them into the country. Local reports as well as the regularity itself of the Spanish-born base of the Gambian pyramid, however, suggest that most children represented in the Gambian pyramid are probably the "own children" of the household. They also suggest that except for brief visits back home, most children born in Spain appear to stay there. Beyond this lies much uncertainty.

In trying to account for the great bulk of the bottom of the Gambian pyramid, we are left with several possibilities, all turning on forms of substitution. Since Gambian children, once they are established in Spain, appear to stay there, most substitutions probably involve women. As such, some of these Gambian-born children in the pyramid could be those of a polygynous wife who returned to Africa to breastfeed a new baby, while another wife replaced her, ready for a new pregnancy when her own child, reaching the stage of weaning, can be left behind with the grandmother. This "man's own children" configuration would be quite legitimate, according to African classificatory kinship practices, in that all children of a man - and his brothers -- are expected to call all his in-married wives, out of respect, "mother." It would also be quite legitimate under the technicalities of reunification policy. Spain may ban polygyny, but neither Spain nor any country I know bans the children by polygynous unions.

Men's efforts to rotate wives between Africa and Spain, resulting in underestimated denominators among mothers who are in Africa, is a very plausible explanation for some of the large number of young Gambian children in Spain. In theory a man could legally bring a second wife as long as he only had one wife at a time in Spain. The fact that Gambian women hope for an honored "retirement" from childbearing means that

33 Farjas (2002), whose thesis focuses on children being sent back to The Gambia to stay with relatives, refers briefly to children sent to Spain to join their immigrant parents or relatives. She describes this as a relatively new practice, an observation that makes sense in that family reunification became possible only in the mid-1990s. 
returning to Africa to be with their families may be exactly what they would like.34 And given the advantages for children of remaining in Spain, women may also prefer to leave their Spanish-born children in the care of the husband and his new wife rather than take them back to Africa. But several things militate against this scenario as an explanation for all cases. Men report intense pressure from home to maintain a steady production of children and to circulate people. There are also stiffening risks for re-entry attempts imposed not just by economic costs but by Spanish reunification policies, a fact that we believe may have produced marked patterns in Spain, and not just African, by "rural-urban" location (Bledsoe et al., ms.).

The most challenging possibility is that some children in Gambian households in Spain may be those of women who remain in Spain, unreported in the official documents. What sort of dynamic might underlie this possibility? First and foremost we bear in mind that each person's position in Spain, whether that of a worker or any of the family members he or she is able to bring, is won at very hard economic and legal cost by someone and usually by multiple people with financial means and effective social contacts. Given this constraint and to avoid the risks of losing legal status and running enormous costs, a "substitution" logic of conjugal life may have emerged among Gambians in Spain: one that emphasizes permanent immigration "slots," rather than assuming the free circulation of an unlimited number of individuals, as is more the case in Africa.

How might such substitutions transpire? To bring a new wife, a man may begin to marginalize an older woman, sending her back to Africa or simply moving her out of the house, or he may allow her to stay as a kind of domestic laborer, moving her to the edges of official visibility as a kind of domestic servant in his household or elsewhere. Whether or not he divorces her, he uses her papers to bring in another wife. And whether the older one remains in Spain or returns to Africa, we may lose count of her in the official record. We resume the count with a new wife who is selected in to the same population in Spain, irrespective of its low fertility norms, precisely for her youthful fecundity: a wife that then takes over the "slot's" papers, hospital records, and so on.35 Either the first or the second wife, of course, may be the one unreported in the official record, but since new wives are likely to be needing health care and social services once they begin bearing children, it is likely the older ones who are edged out of the record. In these ways, a "substitution" pattern arises, in which women continue to arrive - selected in to the migratory stream -- explicitly on the basis of their marriage and reproductive potentials, and selected out when they declare themselves, or others declare them, to be "old." In this way, older wives may be replaced in a continuing cycle by younger ones.

As for children, some of those in Gambian households in Spain may be those of women who remain in Spain, marginalized in the man's household and unreported in the official documents. Others may be children of older wives who were compelled to return home against their wishes so the man could take a new wife. In any case, this mix of legal strictures and economic necessity in Spain, overlaid on top of strong and continuing ties of patronage and kinship to a West African reproductive regime, may have led to a growing accumulation of Spanish-born children who remain in Spain in the wake of multiple acts of wife substitution, or children of other parents who are being brought from The Gambia under the guise of reunification with the man's own children.36 The result may be either an overstated numerator, in the form of an accumulation

34 Attias-Donfut (2004) finds that aging immigrant women in Europe tend to envisage remaining in the new country, while men prefer to return to home.

35 Notably, however, many of their age peers who end up in the UK -- and ironically some of those who remain in The Gambia -- can continue pursuits such as formal education. Kaplan Marcusán (1998:165-66) describes the case of a young Gambian woman who came to a reproductive health clinic in Spain requesting an abortion. She had been trying to pursue her education in The Gambia, but was withdrawn from school by her parents to marry a Gambian man in Spain who was 20 years her senior. Her strategy in requesting the abortion was to appear feign sterility so the husband would send her home to The Gambia, where she could continue her studies. The irony, of course, is marked. The opportunities a place represents are clearly relative to the circumstances of the individuals who arrive, meaning that for some, Africa may represent better prospects for education than Spain.

36 Farjas (2002), whose thesis focuses on children being sent back to The Gambia to stay with relatives, refers to children sent to Spain to join their immigrant parents or relatives. She describes this as a relatively new practice, an observation that makes sense in that family reunification became possible only in the mid-1990s. 
of children of the same man by more than one wife, or an understated denominator, in the form of an unreported second wife, as wives return to Africa or remain at the edges of legitimacy in Spain - or both.37

\section{Gambian women and the 2005 Spanish amnesty}

If the above assessment is correct, then women who are brought to Spain for family reunification may well be dislocated from children as well as husbands. Can the official Spanish data sources lend support to these ethnographic suggestions of both polygyny and wife turnover? Exploring this possibility among "foreigners" in the internet version of the 2001 census would be an obvious step, which I have not yet done. But although this file gives basic age and sex structure of households, still it does not give the marital status of members.

Figures $10 \mathrm{a}$ and $10 \mathrm{~b}$ thus examine change over time in the composition of the population of Gambian nationals in Spain, using the five years since the register began to count Gambians separately to track these changes. Figure 10a shows Gambians, male and female, who were registered in any of the years from 2001 and 2005 (the register only began to distinguish Gambians from the "rest of Africa" in 2001). I use blues to indicate males - dark to light indicating recency - and reds for female. The latest year, 2005, is the only one shown in solid lines, with the male and female triangles/circles, respectively. In this figure, we see two very obvious changes.

Figure 10a

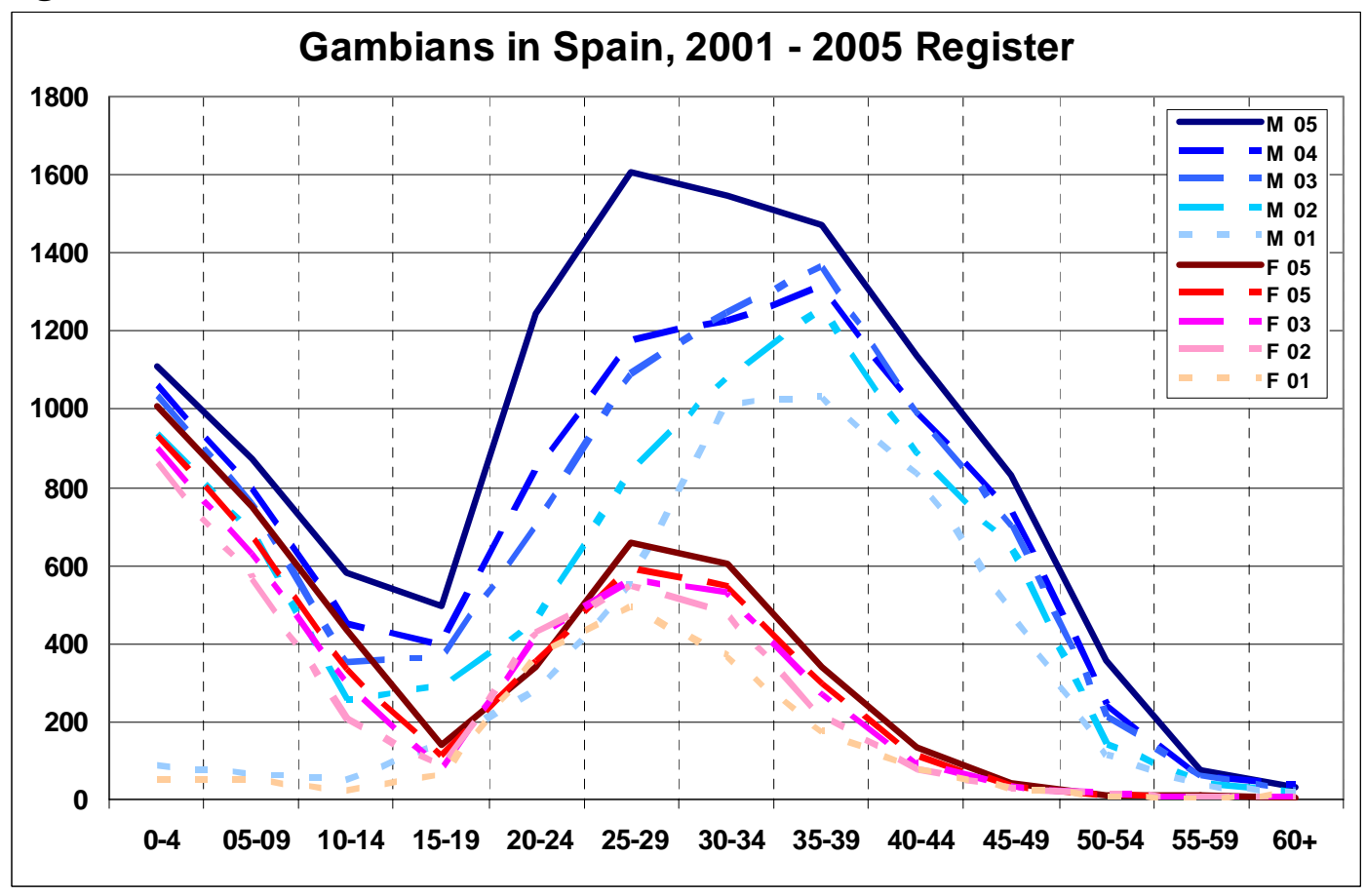

One clear change is in the number of children, represented in 2001 by the palest of male and female lines in the chart. Starting in 2001, Spain loosened its requirements on family reunification, granting automatic rights to dependents of an immigrant who obtained residence papers (Nuria Empez, pers. comm.). The fact that women and children began to come in greater numbers explains the resulting spike in children in 2002. Equally obvious is the increase in men between the ages 20 and 40 from 2004 to 2005, a trend that can only

37 This speculation would be commensurate with the observation of Farjas (2002:290) that Gambian immigrants in Spain - particularly women - live in a precarious "provisional reality" (see also Kaplan, ms.). In Spain, most Gambian women have no citizenship, they do not speak the language, and can be sent home any time by either Spanish authorities or by the man who brought them and who has primary rights in any children they produce. See also Solsona et al. (2003) for an insightful treatment of the connection between reproductive and marital life in Senegal and reproductive health among Senegalese immigrants in Spain 
be explained by the announcement of the 2005 amnesty. The lines representing 2004 and 2005 points to the disproportionate increase in this male age range.

Of most immediate interest to me, though, is another pattern, hardly visible at all in Figure 10a, that surfaces only upon close inspection: an increase in the number of older Gambian women relative to younger ones. Returning to the "magnification" technique, Figure 10b, a derivative of Figure 10a, takes the age range of greatest potential for reproduction for women, converts the differences between 2004 and 2005 to proportions for both genders, and shows the results as bars.

\section{Figure 10b}

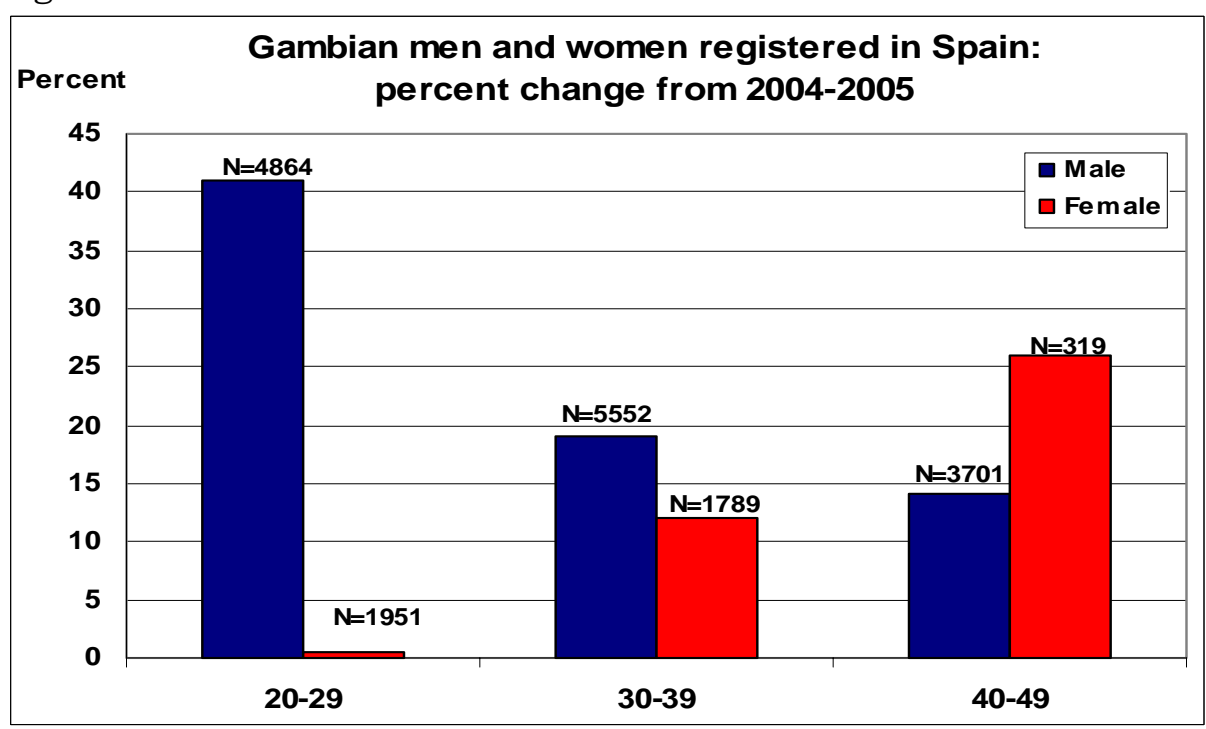

Starting with ages 20-29, Figure 10b shows even more clearly what we saw in Figure 10a, a decisive increment in young male registries, and less strong proportions among older men. If the increase in Gambian men in 2005 was indeed swelled by amnesty applicants, that is, the great majority were probably those in their twenties. For women, the figure shows the exact opposite: an unmistakable increment over the decades, with women in their forties showing by far the largest proportionate gain, and young women, probably continuing a steady pace of marriage-related migration from previous years, showing virtually none.

All this could mean any number of things, of course, including the possible arrival of older Gambian women from France, where some Gambians do in fact live, to take part in the Spanish amnesty. It could also mean that a husband, confronted with the problem of two wives to whom he is attached but one set of papers, divorces one to allow her to obtain papers on her own but continues to maintain marital ties with her. Triangulating from an assortment of ethnography, empirical studies, and quantitative sources, however, I believe that the 2005 amnesty opened up a sudden opportunity for marginalized older Gambian women to surface. These may well have been the same women who had been forced to move out of, or go "underground" within, their own households so the man could accommodate a new wife. Indeed, local people mentioned a small but distinctive type of older Gambian woman who is said to be "emancipated," who begins to take up a life in Spain that is more independent. This is said to be so especially among those women with Spanish-born children, whose children's plights more readily draw the concern of NGOs and Spanish social workers. Finding herself excluded by the "slot" logic of polygamous life in monogamous Spain, such a woman is commonly said to seek out the assistance of NGOs and government services to free herself from her husband and retain her rights to stay.38

38 Even if some came from France, where some Gambians live, this could well be evidence of the same polygyny dynamic. 
In contrast to the prospects of life in Africa, older immigrant women in Spain who are regarded by their husbands as "worn out," whether in the sense of being socially isolated or biologically spent from childbearing, become vulnerable on multiple fronts. As in Africa, however, they are vulnerable to the charms of a desirable young wife who may seek to dominate the attentions of the husband. And they are especially vulnerable to the strength of European laws of monogamy - laws that effectively become policies of exclusion for African families -- that bar the presence of supportive adult children. Older women who have remained below the vision of the formal system and those who take a stand of opposition against their husbands are said to be especially vulnerable to being substituted. The difficulty that families encounter in sustaining a truly polygynous life in the face of strong European laws of monogamy may in fact render older Gambian wives in Spain, separated from their kin at home, more vulnerable than they were in Africa to abuse or neglect. They may also be more vulnerable to being sent home involuntarily in favor of a younger, possibly more docile, but also reproductively active woman. Reports in Europe point consistently to the fact that various forms of sub-rosa polygyny - informal plural unions among residentially separate partners, rapid spousal turnover among serially monogamous men, etc - flourish transnationally. Whether (in the case of Gambians in Spain) such women return to Africa or remain in Spain, whether wife exchange is voluntary or involuntary, whether wives are allowed to remain at the edges of official visibility in Spain - all these dilemmas, in a tense legal context, may heighten the turnover among women of marriageable age.

At the same time, while women in this group may suffer social isolation and become marginalized by "traditional" networks, those women who remain in Spain may find ways in their older years to take up a life in Spain that is independent of the husbands who turned them out. Entering the legal job market, sometimes themselves taking jobs with NGOs or with social and health services themselves, women who remain in Spain may become mediators ("settlers") for new waves of immigrant women who face many of the same problems they did. They may even take up new efforts to circulate people themselves, becoming socially like "men," very much as older women in Africa sometimes do, and begin to arrange the marriages of new young male immigrants who enter the system as low-status clients. As in Africa, one cannot read into this a simple story of the exploitation of women by men. Nor can one read a seamless story of exploitation of immigrants by Spanish citizens, many of whom have rallied both personally and professionally to help undocumented people, despite their government's harsh public policies.

The logic that emerges, irrespective which sources one uses, suggests that the very strength of Spanish laws themselves- laws governing spousal numbers and reunification possibilities renders older Gambian women vulnerable to efforts by husbands to marginalize them. Whether these outcomes occur at the wishes of these women or despite their resistance, and whether the women leave Spain or move to the edges of official visibility in the official records, the intensity of the financial and legal hurdles that Africans face appears to have pressed the Gambian cultural model of marriage in Spain toward a new extreme: a new "slot" dynamic. Informal conversations attest strongly to these patterns, as do the findings from the census and register suggest. Equally important here is that the opportunity that the 2005 amnesty created may have brought a number of older Gambian women out into the open, giving them the legitimacy to incorporate themselves more confidently with their European surroundings. If this interpretation is correct, then the 2005 amnesty may have offered everyone the chance to make the presence of such women legal, and an "officializing" instrument like the register - formerly an enemy - suddenly became an ally.

The results are of course highly provisional. Many uncertainties remain, and many further walls will be hit. Not the least of the problems is that although plays between the numerator and denominator appear to contribute to the high proportion of Spanish-born Gambian children per woman in Spain, the relative contributions of these would be hard to discern. Still, all this hints at a fascinating as well as surprisingly consistent story of the dynamics of integration and exclusion. I personally find the combined power of the ethnographic and official demographic record compelling, and, moreover, the line dividing these genres increasingly meaningless. 


\section{Conclusion}

Interests in patterns based on national origin have drawn considerable attention from anthropologists and sociologists who study transnationalism, and among demographers who study migration. Less conceived are the possible lines of systematic variation among migrants from a single major world region according to their specific nationality. The peculiar situation of an African immigrant group with a more extensive history in Spain gives us a handle on this question, as does the logic of family reunification itself.

The conclusions this exploration have suggested point to some paradoxically divisive, rather than uniting, forces that a stringently enforced vision of family reunification can create. Like any policy measure, the most benign of instruments can exclude as well as include. In so far as family reunification is premised on uniting children with a parent (or maintaining a parent-child unit), therefore, one could call it a half success in this case. If, however, the CRC document is the benchmark, in that the best interests of the child require both parents to be part of the "care and company" picture, then family reunification policy is not just a failure, but possibly the cause of it. Particularly this seems to hold for those migrant populations whose claims to "refugee" status have been the sharpest, and whose needs for family reunification may be the greatest. When turned to weapons of strategic restriction rather than to inclusive generosity, family reunification policies can create the potential for exclusion, creating slots through which individuals may have to rotate. However genuine the efforts by authorities to uphold rights, pressures from other sources create restrictions on adaptations to life in the margins. Such forces may drive underground the dangers to children and the women who produce them: beneath the formal national institutions that purport to support legitimate society members and protect their familial integrity. Indeed, given the sharp constraints imposed by the difficult-and-often-undocumented lives that immigrants must lead, required is deep, continuing engagement

with the home country, itself changing rapidly, in economic support, political alliances, and fluid exchanges of people. Negotiating a precarious new environment itself militates against any notion of "full" integration.

The resulting picture vividly reminds us that any conception of "family formation" as the outcome of free choice by a couple detached from a social and political milieu is misguided, no matter which society we are describing. The conclusions are highly provisional. However, all the results one is able to assemble speak forcefully to the power of the great African "circulation" models that mesh poorly with the narrow, static definitions of spouses and biological children, the basic categories now allowed under family reunification schemes in Europe, and which one sees reflected on the surface of the official census and register sources. At the same time, they speak to the value of seeing these state instruments as potential resources for actors and ways of looking for social scientists. 


\section{APPENDIX}

1. Children described by the popular press as "anchor babies" are Mexican children whose families try to use their births to stake a future claim on legal U.S. residence. The right to citizenship by virtue of a U.S. place of birth is inscribed in constitutional law, giving a child all the privileges and responsibilities that citizenship now entails and the right to family reunification. A child-citizen, upon reaching age 18, may petition to bring his/her parents, spouse, children, and unmarried siblings into the country as legal residents. In effect, a non-U.S. citizen, through one birth, can give an entire family U.S. legitimacy. With U.S. citizenship at such a global premium, geographical contiguity to a much poorer country creates the predictable response. A number of pregnant Mexican women every year feel compelled to try to reach the U.S. to give birth, whether by undertaking dangerous crossings or simply by obtaining 3-day temporary visas available to Mexican individuals who can demonstrate financial stability and a residence close to the border ("A different kind of Border Cross," Chicago Tribune, April 30, 2003).

2. Arranged marriages for immigrant women in Europe have drawn much international press. Less visible is the pivotal role that reproduction seems to play in such cases. The 1997 Norwegian case of an 18 year old woman, "Nadia," sparked furious debate among international activists and scholars (Wikan, 2002a, 2002b). Nadia, 18 at the time, was born in Norway and a Norwegian citizen with Moroccan immigrant parents, who now were naturalized Norwegian citizens. Nadia claimed her parents had drugged, bound, and transported her overland to Morocco in a van, to make her marry a young Moroccan man they had chosen. The international uproar that ensued forced Nadia's parents allow her to return. But the case is instructive for the legal paradoxes it raised. While the parents wanted to stay in Norway, they sought two things: to help a young Moroccan man get to Europe, and to contract a marriage for Nadia to a man whose strong Muslim background would offset what they saw as her loose Norwegian morality. The problem lay in getting her to stay in Morocco. Wikan's descriptions imply that Nadia's parents aimed to make her production of a child in Morocco the condition under which she would be allowed to return to Norway, in that her child's Moroccan citizenship would compel her to remain connected to Morocco. In effect, the children -- and there are two relevant children here, Nadia and her hypothetical Moroccan child - were being used to maintain a hold on both the country of destination and the country of origin.

3. In extreme cases, when legal residence has become most difficult, family reunification is ebbing as a possibility. The only way for some migrants to gain legitimacy is to merge their family life directly with that of people in the destination country. For Cameroonians who seek to go to Germany, exclusionary efforts have become so extreme that legal residence has become next to impossible, unless one marries a German spouse or bear a German child. Annett Fleischer (2005) finds that for Cameroonian women, the best way to stay is to have a child by a German man who will recognize it. For Cameroonian men, many of whom are educated, the route to legal residence is contracting and sustaining a three-year marriage to a German woman. Substantially older than their husbands, most of these women are less willing or able to have a child, making a mandatory three year marriage the default for the man to get papers. Not surprisingly, German fathers of Cameroonian women's children are rarely more than a fleeting presence, and marriages between Cameroonian men and German women are notoriously troubled. In fact, because they need a European partner, Cameroonian immigrants in Germany rarely seem to orient their marital and reproductive lives to one another. And because a Cameroonian man often sees marriage to a German woman as a temporary necessity, looking back to Cameroon for his "real" conjugal future, this renders "traditional" - or at least Cameroonian -- marriage the base, and "formal " marriage in the West as the temporary distortion.

4. Finally, in northern Morocco, is a case of children for whom family reunification has effectively been ruled out altogether: The famed "unaccompanied minors" (see the descriptions of Empez and Galea Montero, 2005). Spain, previously a way station to the rich north of Europe, and a routine place for transnational coming and going for seasonal work, is now an EU member and a target for many young Africans. Those with some degree of wealth manage to come safely, with family reunification arrangements. But for others, Spain is increasingly a dangerous destination. Many Moroccan youth - some pushed by their families, others by their peers -- are led to attempt the journey from the port city of Tangier to the coast of southern Spain across the $14 \mathrm{~km}$ straits of Gibraltar under trucks that board ferry boats or in their shipping containers, or on fishing boats or in pateras, small speedboats. Many who attempt the journey are caught in the port, beaten by police, released far into the hinterland without food or money, and spurned by their families for failing. Those few who manage to reach Spain are caught between Spain's policies on immigration and its laws governing the protection of minors. Youth 
deemed to be aged 18 or over are considered illegal adults and deported. Those below 16 are "repatriated" on the grounds that they are incapable of making a responsible migration decision. But even the 16 and 17 year olds who manage to slip through this tiny window of time and danger face enormous odds. To qualify for papers at age 18, they must stay for several months in centers as the wards of their often-less-than-benevolent guardian, the State, at whose hands they risk violence and mistreatment. While the plight of these "unaccompanied minors" has drawn enormous international concern,39 these Moroccan youth, to qualify for state protection and hence be allowed to stay, must seek the state as their family on the grounds that they have no other family, whether in Spain or in Morocco. Although this oddity appears to have arisen from laws governing the care of minors, the fact that these children must deny that they have any family at all in order to gain entry to Spain means that Spain is effectively excused from the humanitarian demand to allow family reunification.

39 A new study by Empez in Tangier is showing that Spanish immigration policies have also altered socialization practices in northern Morocco. Her study presents a stark case of a poor nation, increasingly impoverished by EU policies of exclusion, where families are in effect trying to produce children specifically for export to Europe. 


\section{References Cited}

Attias-Donfut, Claudine. New patterns of migration and transmigration: a life course perspective. European Regional Meeting, Migrants and Social Protection, European Regional Meeting. Oslo, Norway. ISSA/EUR/OSLO/04. http://www.issa.int/pdf/oslo04/2attias.pdf\#search='attiasdonfut $\% 20$ migration'

Barnes, Sandra T. 1987. "The urban frontier in West Africa: Mushin, Nigeria." The African Frontier: the Reproduction of Traditional African Societies. Igor Kopytoff, ed. Bloomington: Indiana University Press, pp. 255-281.

Bledsoe, Caroline. 1990. "'No success without struggle': social mobility and hardship for Sierra Leone children." Man (N.S.) 25:70-88.

Bledsoe, Caroline H., with contributions by Fatoumatta Banja. 2002. Contingent Lives: Fertility, Time and Aging in West Africa. Chicago: University of Chicago Press.

Bledsoe, Caroline H., René Houle, and Papa Sow. Ms. "High fertility Gambians in low fertility Spain: The dynamics of child accumulation across transnational space." Special issue of Demographic Research (forthcoming). Laura Bernardi and Inge Hutter, eds.

Bledsoe, Caroline H. and Papa Sow. Ms. "Emancipation or marginalization: the dilemmas of aging Gambian women in Spain.” Paper for the European Fertility Conference. Liverpool, England.

Cabré, Anna. 1999. El Sistema Català de Rreproducció. Barcelona: Proa.

Calavita, Kitty. 2005. Immigrants at the Margins: Law, Race, and Exclusion in Southern Europe.

Cambridge: Cambridge University Press.

Clignet, Remi. 1970. Many Wives, Many Powers: Authority and Power in Polygynous Families. Evanston, IL:

Northwestern University Press.

Cole, Jennifer and Deborah Durham, eds. In press. Generations and Globalization: Youth, Age, and

Family in the New World Economy. Bloomington, Indiana: Indiana University Press.

Comaroff, John L. and Simon Roberts. 1977. "Marriage and extra-marital sexuality: the dialectics of legal change among the Kgatla," Journal of African Law 21:97-123.

Dinan, Carmel. 1983. Sugar daddies and gold-diggers: The white-collar single women in Accra. In

Female and Male in West Africa. C. Oppong, ed. London: George Allen \& Unwin, pp. 344-366.

Domingo, Andreu, Jaume Clapes Estrada, and Maria Prats Ferret. 1995. Condicions De Vida De La

Població D'origen Africa I Llatinoamericà a La Regió Metropolitana De Barcelona: Una Aproximació Qualitativa. Barcelona: Mancomunitat de Municipis de l'Area Metropolitana de Barcelona y Diputació de Barcelona.

Domingo, Andreu, Ines Brancos i Coll, Jordi Bayona i Carrasco. 2002. Migracions Internacionals $i$ Poblacio Jove de Nacionalitat Estrangera a Catalunya. Generalitat de Catalunya, Departament de la Presidencia, Secretaria General de Joventut, Generalitat de Catalunya, No. 7.

Domingo, Andreu and René Houle. 2005. "The economic activity of foreign population in Spain: between complementarity and exclusion." Paper for the International Union for the Scientific Study of Population. 25th International Population Conference. Tours, France. July 18-23, 2005

Domingo, Andrew and I. Brancos. 1996. "Aspectes demogràfics de la immigració estranjera a les comarques barcelonines." Papers de Demografia, 116, Barcelona: Universitat Autònoma de Barcelona, Centre d'Estudis Demogràfics.

Edwards, Jeanette, Sarah Franklin, Eric Hirsch, Frances Price, and Marilyn Strathern, eds. 1999. Technologies of Procreation: Kinship in the Age of Assisted Conception. London: Routledge.

Empez, Nuria and Vicens Galea Montero. 2005. "Family strategies and unaccompanied migrant minors." Paper for the European Association of Population Studies, Working Group on the Anthropological Demography of Europe. Max Planck Institute for Demographic Research. Rostock, Germany.

Enel, Catherine, Gilles Pison, and Monique Lefebvre. 1994. "Migration and marriage change: a case study of Mlomp, a Joola village in southern Senegal." Nuptiality in Sub-Saharan Africa: Contemporary Anthroplogical and Demographic Perspectives. Caroline Bledsoe and Gilles Pison, eds., pp. 92-113.

Escrivá, Angeles. 2005. "Aged global care chains: a southern-European contribution to the field." International Conference on Migration and Domestic Work in Global Perspective Wassenaar, May 2005.

Escrivá, Angeles and Emmeline Skinner. 2006. "Moving to Spain at an advanced age." Generation Review 16(2):8-15. 
Farjas i Bonet, Anna. 2002. El Process Migratori Gambià a Comarques Gironines: El Cas de Banyoles, Olot i Salt. Doctoral Thesis presented at the Department de la Pedagogia, Universitat Girones.

Fleischer, Annett. 2005. "The influence of family and kin network on the decision to migrate: some evidence from Cameroon.” Paper for the European Association of Population Studies, Working Group on the Anthropological Demography of Europe. Max Planck Institute for Demographic Research. Rostock, Germany.

Franklin, Sarah and Helena Ragoné. 1998. Reproducing Reproduction: Kinship, Power, and Technologica Innovation. Philadelphia: University of Pennsylvania Press.

Ginsburg, Faye D. and Rayna Rapp, eds. 1995. Conceiving the New World Order: The Global Politics of Reproduction. Berkeley: University of California Press.

Goody, Esther N. 1973. Contexts of Kinship: an Essay in the Family Sociology of the Gonja of Northern Ghana. Cambridge: Cambridge University Press.

Hart, Keith. Forthcoming. "The persuasive power of money," Persuasion in Economic Life. Berghahn Books.

Hochschild, Arlie. 2000. "The nanny chain." The American Prospect 11(4):

Hoggart, Keith and Cristóbal Mendoza. 2000. "African immigrant workers in Spanish agriculture."

Working Paper No. 2, Center for Comparative Immigration Studies. La Jolla, California.

Hondagneu-Sotelo, Pierrette. 2002. "Families on the Frontier: From Braceros in the Fields to

Braceras in the Home." Latinos: Remaking America. Marcelo Suarez-Orozco, ed. Cambridge, MA: Harvard University Press. Pp. 259-273.

Hondagneu-Sotelo, Pierrette. 1995. "Women and Children First: New Directions in Anti-immigrant

Policy." Socialist Review 25(1): 169-190.

Inda, Jonathan Xavier. 2002. "Biopower, reproduction, and the migrant woman's body." Decolonial

Voices: Chicana and Chicano Cultural Studies in the 21 st Century. Edited by Arturo J. Aldama and Naomi

Quiñonez, pp. 98-112. Bloomington: Indiana University Press.

Jastram, Kate. 2003. "Family unity: the new geography of family life." Migration Information Source. Migration Policy Institute. May 1, 2003.

http://www.migrationinformation.org/Feature/display.cfm?ID=118

Johnson-Hanks, Jennifer. 2006. An Uncertain Honor: Modern Motherhood in an African Crisis. Chicago:

University of Chicago Press.

Kahn, Susan Martha. 2000. Reproducing Jews: A Cultural Account of Assisted Conception in Israel. Durham:

Duke University Press.

Kaplan-Marcusán, Adriana. 1998. De Senegambia a Cataluña: Procesos de Aculturación e Integración Social.

Barcelona: Fundación "la Caixa."

Kaplan Marcusán, Adrianna. Ms. "Procesos migratorios, transformaciones culturales e identitarias:

Senegambianos en Cataluña."

Kulu, Hill. 2005. "Migration and fertility: competing hypotheses re-examined." European Journal of

Population 21(1):51-87.

Lardoux, Solène and Étienne van de Walle. 2003. "Polygyny and fertility in rural Senegal." Population 58(6):717-44.

Locoh, Thérèse (1994) "Social change and marriage arrangements: new types of union in Lomé,

Togo." Nuptiality in Sub-Saharan Africa: Contemporary Anrhopological and Demographic Perspectives. Caroline Bledsoe and Gilles Pison, eds. Oxford: Clarendon Press, pp. 215-230.

McKinnon, Susan and Sydel Silverman eds. 2005. Complexities: Beyond Nature \& Nurture. Chicago: University of Chicago Press.

Miret, Pau. 2000. "Fathers and families in contemporary Spain: from dictatorship to democracy."

Fertility and the Male Life Cycle in the Era of Fertility Decline. Caroline Bledsoe, Susana Lerner, and Jane Guyer, eds. Clarendon: Oxford University Press, pp. 275-290.

Murphy, William P. and Caroline H. Bledsoe. 1987. "Territory and matrilateral kinship in the history of a Kpelle chiefdom." The African Frontier: The Reproduction of Traditional African Societies. Igor Kopytoff, ed. Indiana University Press, pp. 121-147.

Oakley, Ann. 2005. The Ann Oakley Reader: Gender, Women and Social Science. Bristol: Policy.

Parkin, David J. and David Nyamwaya. 1987. Transformations of African Marriage. Manchester:

Manchester University Press for the International African Institute. 
Randall, Sara and Thomas LeGrand. 2003. "Reproductive strategies and decisions in Senegal: the role of child mortality." Population 58(6):687-715

Rapp, Rayna. 1999. Testing Women, Testing the Fetus: the Social Impact of Amniocentesis in America. New York: Routledge.

Recano-Valverde, Joaquin and Andreu Domingo. 2005. "Factores sociodemográficos y territoriales de la inmigración irregular en España." Paper for the International Union for the Scientific Study of Population. 25th International Population Conference. Tours, France. July 18-23, 2005.

Rodríguez García, Dan. 2001. "Inmigración africana hacia Europa, cun proceso sin fin?. El caso de Gambia," Ô Willaeri (La cooperació). Barcelona: ETANE, especial 10ª Diada Cultural Afrocatalana, 1, Junio 2001.

Rodríguez García, Dan. 2004. Inmigración y Mestizaje Hoy: Formación de Matrimonies Mixtos y Familias Transnacionales de Población Africana en Cataluña. Bellaterra: Universitat Autònoma de Barcelona, Servei de Publicacions.

Roig Vila, Marta and Teresa Castro Martín. 2005. "Immigrant mothers, Spanish babies: longing for a baby-boom in a lowest-low fertility society." Paper for the International Union for the Scientific Study of Population. 25 th International Population Conference. Tours, France. July 18-23, 2005.

Sargent, Carolyn and Dennis Cordell. 2003. "Polygamy, disrupted reproduction, and the state: Malian migrants in Paris, France." Social Science and Medicine 56(9):1961-72.

Sonko, Sheriffo. Ms. Fertility Decline in The Gambia: Trends and Differentials. Draft Report. UNICEF Banjul. Central Statistics Department. Department of State for Finance and Economic Affairs. Banjul, The Gambia.

Sow, Papa. 2004a. "Prácticas comerciales transnacionales y espacios de acción de los senegaleses in España." Migración y Desarrollo Estudios sobre Remesas y Otros Prácticas Transnacionales in España. Natalia Ribas y Ángeles Ecrivá, eds. Córdoba: Consejo Superior de Investigaciones Científicas, Instituto de Estudios Sociales de Andalucía, pp. 235-254.

Sow, Papa. 2004b. "Mujeres inmigrantes y/o esposes de inmigrantes senegaleses y gambianos en Cataluña (España): entre la vida familiar y la vida professional.” Doc. Anàl. Geogr. 43, pp. 69-88.

Thompson, Charis. 2005. Making Parents: The Ontological Choreography of Reproductive Technologies.

Boston: MIT Press.

United Nations. 2000. "Replacement Migration: Is it a solution to declining and ageing population?" United Nations Department of Economic and Social Affairs, Population Division, United Nations. New York.

http://www.un.org/esa/population/publications/migration/execsum.pdf\#search='United $\% 20$ nations\%20re placement $\% 20$ migration'

Whiteford, Linda M. and Lenore Manderson eds. 2000. Global Health Policy, Local Realities: The Fallacy of the Level Playing Field. Lynne Rienner Publishers, 2000.

Wikan, U., 2002(a). "Citizenship on trial: Nadia's case." In: Shweder, Richard, Martha Minow, and Hazel Markus, eds. Engaging Cultural Differences: The Multicultural Challenge in Liberal Democracies. New York: Russell Sage Foundation. Pp. 128-143.

Wikan, U., 2002(b). Generous Betrayal: Politics of Culture in the New Europe. Chicago: University of Chicago Press. 